\title{
REPERTORIO BIBLIOGRAFICO SOBRE FEDERALISMO, NACIONALISMO Y REGIONALISMO
}

\author{
POR \\ JAVIER GARCIA FERNANDEZ \\ Profesor ayudante de Derecho Político \\ Facultad de Derecho de la Universidad Complutense
}

La regulación de las autonomías nacionales y regionales en nuestra Constitución ha vuelto a plantear con inusitada intensidad el tema de la distribución territorial del poder. Algunos comentaristas, quizá no de buena fe, se han planteado qué diferencia práctica existe entre el tratamiento regional que aparece en la Constitución de 1978 y el federalismo. Posiblemente la pregunta tenga un trasfondo interesado, pero es evidente que las categorías clásicas (Estado federal, Estado unitario) van adquiriendo una importancia relativa, importancia que quedó aún más disminuida cuando Ambrosini, en la década de los treinta, puso en circulación una nueva categoría, la del Estado regional.

Posiblemente tengan razón los autores que consideran que entre el Estado federal «clásico» y las distintas formas de regionalización no hay más que una diferencia cuantitativa, pero no cualitativa, sobre todo cuando la otra categoría "clásica» - la del Estado unitario- va quedando reducida a Estados de escasa extensión territorial (donde también se empieza a plantear el tema regional, como en Portugal). Puede decirse que todo Estado con una extensión geográfica media conoce actualmente procesos o tensiones descentralizadores y que estos procesos y tensiones ponen en cuestión las concepciones clásicas del federalimo y del regionalismo.

Resulta imprescindible plantearse de una forma unificada el tema de la distribución territorial. Estado federal y Estado regional son dos categorías actualmente complementarias que requieren un tratamiento científico conjunto. Pero este tratamiento no puede dejar al margen la categoría complementaria de la nación. Sin delimitar el concepto de nación (no por clásico de menos actualidad) no se puede analizar correctamente el fenómeno federal y el fenómeno del Estado regional, tanto si guiamos el análisis hacia un pleno institucional como si lo hacemos desde la perspectiva de las doctrinas políticas.

Por eso tenía interés fijar en un repertorio bibliográfico unificado la producción científica disponible. Áhora bien, la elaboración de este repertorio planteaba el problema de los límites de la bibliografía a recoger. Los repertorios clásicos de Karl Deutsch, Robert L. Merritt y de Pinson resultan, amén de inencontrables, bastante limitados. Era aconsejable introducir un criterio de selección que proporcionara operatividad a la recopilación.

El presente repertorio se ha elaborado por ello con dos criterios complementarios. En cuanto al tipo de obras seleccionadas, se ha pretendido recoger la producción más reciente, la cual ha primado sobre las más antiguas, pero sin desdeñar las obras que pueden considerarse clásicas, las cuales se recogen cuando han reci- 
bido una digna cualificación en la doctrina más solvente. En cuanto al contenido de la selección, se ha utilizado una triple clasificación: obras de enfoque general sobre federalismo, nacionalismo y regionalismo; Estados que se han estructurado o se quieren estructurar de forma federal o regional; por último, bibliografía sobre España.

Incluir en un mismo apartado toda la bibliografía sobre federalismo, nacionalismo y regionalismo no planteaba desde el punto de vista conceptual mayores dificultades, pero era necesario distinguir la producción científica volcada a analizar estos tipos de Estado y la producción dedicada a analizar las doctrinas e ideologías nacionalistas o federalistas. $Y$ dentro de estas doctrinas resultaba aconsejable elaborar un apartado independiente dedicado al controvertido tema de las relaciones entre marxismo y cuestión nacional, tema de permanente actualidad porque se resiste a dar espaldarazo político a las formulaciones clásicas, que desde los austromarxistas hasta Stalin han pretendido cerrar un tema que lucha por desasirse de todo planteamiento acabado.

Al entrar en la parte «comparatista» del repertorio había la posibilidad de centrarse exclusivamente en los Estados más conocidos, pero un mínimo rigor exigía no marginar experiencias federales discutibles o marginales (Camerún, Malasia, Venezuela), aunque sólo sea por constatar las dificultades que arrastran los modelos más clásicos en algunas áreas alejadas de Europa. De ahí que se hayan agregado algunas referencias «exóticas», aunque se sea consciente de su escaso interés práctico.

Por último, al recoger la información bibliográfica sobre España se planteaba el problema de reducir ésta a lo que ahora más interesa, que es el tratamiento autonomista que lleva la Constitución de 1978, sobre todo cuando existe el interesante repertorio de Orduña Rebollo, recogido en el número 13 de Documentación Jurídica. Pero es evidente que el tema nacional-regional no se limita en España a su formulación constitucional y que además éste se pierde ya en la noche de los siglos. Por eso se ha optado por una solución intermedia. Recoger con criterios muy selectivos la producción básica que analiza históricamente el tema de las nacionalidades y regiones (insistiendo un tanto en la producción dedicada a la Segunda República por su valor referencial) y centrar la aportación bibliográfica en la producción más reciente, tanto sobre los análisis políticos del problema como sobre la ya numerosa producción nacida al amparo de la nueva Constitución.

Se ha prescindido totalmente de los tratados y manuales, tanto españoles como extranjeros, que contienen importantes estudios del problema. En este sentido, obras como las de Lucas Verdú y Friedrich son indispensables, pero ha parecido más correcto no incluir este tipo de producción que, por otra parte, está al alcance de cualquier estudioso. Finalmente, se ha dado primacía a la producción española y luego a la que ha sido escrita en los idiomas más accesibles para el investigador español (francés, italiano, inglés y alemán), pues recurrir a otros idiomas de difícil acceso para la mayoría de los científicos españoles no habría pasado de ser un alarde innecesario de falsa erudición. 
1. PROBLEMATICA GENERAL DE LA DISTRIBUCION TERRITORIAL DEL PODER Y DE LOS ESTADOS COMPUESTOS Y PLURINACIONALES

\subsection{Introducción al federalismo y al regionalismo}

1. Chiossone, Tulio: La forma del Estado. Centralismo y federalismo, Empresa El Cojo C. A., Caracas, 1961.

2. Deutsch, Karl W., y MerRITT, Robert L.: Nationalism: An Interdisciplinary Bibliography: 1935-1965, The M.I.T. Press, Cambridge, Mass., 1966.

3. Ferrando, Juan: «El Estado unitario», Revista de Estudios Politicos, números 195-196, mayo-agosto 1974, págs. 9-47.

4. Ferrando, Juan: El Estado unitario, el federal y el Estado regional, Tecnos, Madrid, 1978.

5. Gavira, Carmen, y Gómez Orfanel, Germán: «Poder, espacio y democracia», Revista de Estudios Sociales, núms. 21-22, septiembre-diciembre 1977/ enero-abril 1978, págs. 15-20.

6. GOMEZ Orfanel, Germán: «Las situaciones de conflicto entre poderes centrales y poderes autónomos: Prusia (1932) y Cataluña (1934)», Argumentos, núm. 17, noviembre 1978, págs. 59-60.

7. LuCas Verdú, Pablo: «Centralismo-Regionalismo-Federalismo (Tres principios configuradores del Estado contemporáneo)», Documentación Jurídica, núm. 13, enero-marzo 1977, págs. 43-71.

8. Pinson, K. S.: A Bibliographical Introduction to Nationalism, Columbia University Press, Nueva York, 1935.

9. PRATS, Yves: Décentralisation et développement, Cujas, París, 1973.

10. Rubiales, Amparo: «Aproximación a los conceptos de Nación, Región y Estado desde una perspectiva jurídica», Civitas. Revista Española de Derecho Administrativo, núm. 15, octubre-diciembre 1977, págs. 629-642.

\subsection{Introducción a los Estados compuestos}

11. Rolef, Susan Hattis: «The Multi-National State», Res Pública, vol. 16, número 1, 1974, págs. 89-115. 
12. SAVARD, J. G., y Vegneault, R. (eds.): Les Etats multilingues: problémes et solutions, Presses de l'Université Laval, Québec, 1974.

13. Touret, Bernard: L'aménagement constitutionnel des Etats de peuplement composite, Presses de l'Université Laval, Québec, 1973.

\subsection{Minorías}

14. Ashworth, Georgina (ed.): World Minorities, Quartermaine House, Sunbury, 1977.

15. BAGET Bozzo, Gianni: «Le nazionalità subalterne: piccole patrie senza Stato», Rinascità, año 36, núm. 20, 25 mayo 1979, págs. 30-31.

16. Busquets, Julio: «Las minorías, sus problemas y posibles soluciones», $R e$ vista de Estudios Sociales, núm. 1, enero-abril 1971, págs. 181-209.

17. Rodinson, Maxime: «De la nation juive au problème juive», L'bomme et la société, núm. 9, julio-septiembre 1968.

\section{FEDERALISMO, NACIONALISMO, REGIONALISMO}

\subsection{El Estado federal}

18. Aguilar Navarro, Mariano: «El federalismo como técnica y como ideología», Anales de la Universidad Hispalense, núm. 3, 1950, págs. 7-25.

19. Albertini, Mario: Il federalismo. Antologia e definizione, Il Mulino, Bolonia, 1978.

20. Ambrosini, G.: Autonomia regionale e federalismo (Austria, Spagna, Germania, URSS), Ed. Italiane, Roma, 1945.

21. ARON, Raymond: «A Suggested Scheme for the Study of Federalism», International Social Science Bulletin, 1952, págs. 45-53.

22. Brunialti, Attilio: Unioni e Combinazioni fra gli Stati, gli Stati composti e lo Stato federale, Biblioteca di Scienze Politiche, Turín, 1891.

23. BERNIER, Ivan: International legal aspects of federalism, Logman, Londres, 1973.

24. BrRch, A. H.: «Approaches to the Study of Federalism», Political Studies, 1966, págs. 15-33.

25. BowIE, Robert R., y FRIEDRICH, Carl J.: Estudios sobre federalismo, Buenos Aires, 1953.

26. Bothe, Michael: Die Kompetenzstruktur des modernen Bundesstaates in rechtsvergleicbender Sicbt, Max Planck Institut/Springer, Heidelberg, 1977.

27. Brungmans, Henri, y Duclos, Pierre: Le féderalisme contemporain, Leyden, 1963.

28. Cordero Torres, José María: Del federalismo al regionalismo: la evolución de los federalismos contemporáneos, Real Academia de Ciencias Morales y Políticas, Madrid, 1971.

29. Durán y Ventosa, Lluis: Regionalisme y Federalisme, Francisco Puig, Bar celona, 1905.

30. Durand, Ch.: Conféderation d'Etats et Etat féderal, Marcel Riviére, París, 1955.

31. EFrAT, Edgar S.: «Federations in Crisis. The Failure of the Old Order», The Western Political Quarterly, vol. 25, núm. 4, diciembre, 1972, páginas 589-599. 
32. Ferrando, Juan: «El federalismo», Revista de Estudios Politicos, núms. 206207, marzo-junio, 1976, págs. 23-73.

33. Franck, T.: Why Federations Fail: An Inquiry into the Requisites for Succesful Federalism, Nueva York, 1968.

34. FrIedrich, Carl J.: Tendences du féderalisme en théorie et en pratique, Institut Belge de Science Politique, Bruselas, 1971.

35. FrIEDRICH, Carl J., y KRAUS: «Zum gegenwärtigen Stand des Föderalismus in der Vereinigten Staaten», Jabrbuch der öffentlichen Rechts, 1936, págs. 343-375.

36. HEUbl, Franz: «Föderalismus als Modell für Staat und Gesellschaft von morgen», Politische Studien, mayo-junio 1972.

37. Jallon, André: Le féderalisme, Presses Universitaires de France, París, 1971.

38. KirchHeImer, Otto: «The Decline of Intraestate Federalism in Western Europe», World Politics, núm. 3, 1953.

39. KISKER: Kooperation im Bundesstaat, Tubinga, 1971.

40. Kunz, J. L.: «Une nouvelle théorie de l'Etat féderal», Revue du droit international et de legislation comparée, 1930.

41. La Pergola, Antonio: Sistema federale e «compact» clase, Milán, 1961.

42. Le Fur, M.: La Confédération d'Etats et l'Etat féderal, Marchal et Billards, París, 1896.

43. Livingstone, William, S.: Federalism and Constitutional Change, Clarendon Press, Oxford, 1956.

44. LuCAS Verdú, Pablo: «Confederación», Nueva Enciclopedia Jurídica, Francisco Seix, Barcelona, 1952, tomo IV, págs. 910-918.

45. Lucas Verdú, Pablo: «Estado federal», Nueva Enciclopedia Jurídica, Francisco Seix, Barcelona, 1958, tomo IX, págs. 1-56.

46. Lucas Verdú, Pablo: «Federación», Nueva Enciclopedia Jurídica, Francisco Seix, Barcelona, 1958, tomo IX, págs. 668-674.

47. Lucatello, G.: Lo Stato federale, Cedam, Padova, 1939.

48. Macmahon, Arthur W.: Administaring federalism in a democracy, Oxford University Press, Nueva York, 1972.

49. Marriot, J. A. R.: «Nationalism and Federalism», Quarterly Review, 1940.

50. Marriot, J. A. R.: «Problems of Federalism», Quarterly Review, 1941.

51. Medina Echevarría, José: «La panacea del federalismo», Cuadernos Americanos, vol. 19, enero-febrero, 1945 , págs. 28-48.

52. Mogr, S.: The Problem of the Federalism, Londres, 1931.

53. Mouskhely, Michel: La teoria jurídica del Estado federal, Aguilar, Madrid, 1931.

54. Munch, Fritz: Föderalismus Volkerrecht und Gemeinschaften im Die öffentliche Verwaltung, 1962.

55. RrkeR, W. H.: Federalism, origin, operation, significance, Little Brown, Boston, 1964.

56. SAWER: Modern Federalism, Londres, 1966.

57. Schepers, Stefan: «Le féderalisme, de la Grèce antique aux Provinces Unies des Pays-Bas», Res Publica, vol. 18, núm. 2, 1976, págs. 167-178.

58. Serra Moret, Manuel: «Nacionalización y federalismo», Galeuzca, núm. 11, junio 1946.

59. Solé-Tura, Jordi: «Nacionalidades y Estado federal», en el vol. col. Asalto al centralismo, Avance, Barcelona, 1976, págs. 29-35.

60. WaTTS: New Federations: Experiments in the Commonwealth, Londres, 1966.

61. WheARe, K. C.: Federal Government, Oxford University Press, Oxford, 1953. 
62. WIGNEY, Pierre: «Le Féderalisme», Revue Générale Belge, septiembre 1962.

63. Yarbrough, Tinsley E.; MYer, Dom H. de, y East, John P. (eds.): Trends in Federalism, East Carolina University Press, Greenville (N. C.), 1972.

\subsection{El pensamiento federalista}

64. BANCAL, Jean: «Le féderalisme proudhonien: au delá de l'éclatement des Etats-nations et de la politique de blocs, une voie de liberté», Revue de travaux de l'academie des sciences morales et politiques, año $124,4 .^{\mathrm{a}}$ serie, décimo trimestre, 1971, págs. 141-171.

65. Brugmans, Henri: La pensée politique du féderalisme, A Sythoff, Leyden, 1969.

66. Davis, Rufus S.: The Federal Principle: A Jorney Tbrough Time in Quest of Meaning, University of California Press, Berkeley (Ca.), 1978.

67. Deuerlein, Enst: Föderalismus - Die bistoriscben und philosopbiscben Grundlagen des föderativen Prinzips, Schriftenreihe des Bundeszentrale für politische Bilding, Bonn, 1972.

68. HAHN, Karl: Föderalismus. Die demokratische Alternative. Eine Untersuchung zu P. J. Proudons sozial-republikanisch-föderativen Freibeitsbegriff. E. Vögel, Munich, 1975.

69. La Pergola, Antonio: «El 'empirismo' en el estudio de los sistemas federales: en torno a una teoría de Carl Friedrich», Revista de Estudios Politicos, núm. 188, marzo-abril 1973, págs. 21-77.

70. Rogers: «The Political Principles of Federalism», Journal of Economics and Political Science, 1935.

71. Voyenne, Bernard: Histoire de l'idée federaliste, Presses d'Europe, París, 1973.

\subsection{La nación. El Estado nacional}

72. Albertini, Mario: L'Etat national, Fédérop, Lyon, 1978.

73. AMIN, Samir: «La línea burguesa y la línea proletaria en la cuestión nacional», El Viejo Topo, núm. 27, diciembre 1978, págs. 4-7.

74. Azkin, Benjamín: Estado y Nación, Fondo de Cultura Económica, México, 1968.

75. BeLL, Wendell, y FreEMAN, Walter E. (eds.): Etbnicity and nationbuilding. Comparative, international and bistorical perspectives, Sage, Beverly Hills, California, 1974.

76. Bourque, Gilles: L'Etat capitaliste et la question nationale, Presses de l'Université de Montreal, Montreal, 1977.

77. BusqueTs, Julio: Introducción a la sociologia de las nacionalidades, Edicusa, Madrid, 1971.

78. CAMPBELI, Ernest Q. (ed.): Racial tensions and national identity, Vanderbilt University Press, Nashville (Tenn.), 1972.

79. Снавор, F.: L'idea di nazione, Laterza, Bari, 1974.

80. DanN, Otto (ed.): Nationalismus und sozialer Wandel, Hoffmann und Campe, Hamburgo, 1978.

81. Delos, J. T.: La nación, Buenos Aires, 1948.

82. DíAz de Liaño y Fernández, Fernando: «El Estado-Nación y su crisis. Distintas alternativas al mismo. Especial referencia a la descentralización», $R e$ vista de Estudios Sociales, núms. 21-22, septiembre-diciembre 1977/eneroabril 1978, págs. 21-41. 
83. Ehrlich, Stanislas: «L'Etat et la Nation», L'Homme et la Societé, números 24-25, abril-septiembre 1972, págs. 177-186 (también en Res Publica, vol. 15, núm. 1, 1973, págs. 93-102).

84. Eisenstadt, Samuel N., y Rokkan, S. (eds.): Building State and Nation, Sage, Beverly Hills (Ca.), 1974.

85. Emerson, R.: From Empire to Nation, Harvard University Press, Cambridge (Mass.), 1960.

86. Ferrando, Juan: «La nación», Revista de Estudios Políticos, núm. 202, julio-agosto 1975 , págs. 5-56.

87. Hertz, F.: Nationality in History and Politics, Londres, 1951.

88. HoвSBAWM, Eric: Mouvements nationaux d'indepéndence et classes populaires aux XIX et XX siècles, París, 1971.

89. JohanNET: Le principe des nationalités, París, 1918.

90. Kalmanovitz, Salomón: «Notas sobre la formación del Estado y la cuestión nacional en América Latina», Ideología y Sociedad, núm. 20, enero-marzo 1977, págs. 33-58.

91. KARDELJ, Edward: «La nation et les relations internationales», Questions actuelles du socialisme, año 25 , núms. $7-8,1975$, págs. 3-36; año 25 , número 9, 1975, págs. 3-39.

92. Kurtovic, Todo: «La révolution, les libertés nationales et l'egalité des droits», Questions actuelles $d u$ socialisme, año 25 , núms. 7-8, 1975, páginas 37-74; año 25, núm. 9, 1975, págs. 40-66.

93. LAFONT, Robert: Teoria de la nació, Edicions 62, Barcelona, 1969.

94. Mandel, Ernest: «Question nationale et luttes de classes dans les pays impérialistes», Contradictions, núm. 3, enero-junio 1973.

95. Maugue, Pierre: «Nation et Etat», Etbno-Psychologie, año 30, núms. 3-4, septiembre 1975, págs. 411-430.

96. Moya, Carlos: «Estado nacional y mercado mundial», Sistema, núms. 29-30, mayo 1979 , págs. $27-41$.

97. Murillo FERrol, Francisco: «Nación y crisis», Revista de Estudios Políticos, núm. 58, julio-agosto 1951 , págs. 47-76.

98. Murillo Ferrol, Francisco: «La nación y el ámbito de la democracia», Sistema, núm. 26, septiembre 1978, págs. 3-19.

99. PI-SUNYER, Oriol (ed.): The Limits of Integration: Etbnicity and Nationalism in Modern Europe, University of Massachusetts, Boston, 1971.

100. PonteIl, Felix: L'eveil des nationalités et le mouvement national, Presses Universitaires de France, París, 1960.

101. Poulantzas, Nicos: «L'internationalisation des rapports capitalistes et 1'EtatNation», Les Temps Modernes, núm. 319, febrero 1973.

102. Renan, Ernest: ¿Qué es una nación?, Instituto de Estudios Políticos, Madrid, 1957.

103. Riвó, Rafael: «Base théorico-réelle des exposés ideologiques et strategiques de la question nationale», Contradictions, núm. 4, julio-diciembre 1973.

104. Riвó, Rafael: «Aproximació metodològica al fet nacional», Recerques, número 4, 1974, págs. 117-135.

105. RIB6, Rafael: «Conceptes Politics i realitat nacional», Taula de Canvi, número 3, enero-febrero 1977, págs. 35-48.

106. Ródenas, Pablo: «Nacionalidad, nación e imperialismo», El Cárabo, núm. 5, marzo-abril 1977, págs. 103-134.

107. Rodinson, Maxime: Sobre la cuestión nacional, Anagrama, Barcelona, 1975.

108. RodrígueZ ZúÑIGA, Luis: «Marcel Mauss y la nación como tipo social», Revista Española de la Opinión Pública, núm. 42, octubre-diciembre 1975, págs. 55-80. 
109. Rubio García, Leandro: «La patria en la nueva dinámica internacional», Las Ciencias, año 29, núm. 1, 1964, págs. 34-42.

110. RuIz DEL Castillo, Carlos: Crisis y porvenir de la idea de Nación, Madrid, 1945.

111. SÁnCHEZ AgeSTA, Luis: «Concepto histórico político de Nación», Revista General de Legislación y Jurisprudencia, tomo 170, núm. 6, diciembre 1941, págs. 535-566.

112. SATHYAMURTHY: «Les nouveaux Etats: double dynamique et conflits», Cabiers internationaux de sociologie, vol. 61, 1976, págs. 271-296.

113. Setmana dels Intellectuals Católic de Franca: La consciència cristiana $i$ els nacionalismes, Estela, Barcelona, 1969, 2.a ed.

114. Seton-Watson, Hung: Nations and States (An Enquiry into the Origens of Nations and the Politics of Nationalism), Methuen, Londres, 1977.

115. SmitH, Anthony D.: «L'idée de nation», Annales de Pbilosopbie politique, núm. 8, 1969, págs. 7-62.

116. Solé-Tura, Jordi: «Historiografía y nacionalismo. Consideraciones sobre el concepto de nación», Boletín Informativo de la Fundación Juan March, número 42, octubre 1975, págs. 3-14 (reproducido en el vol. col. Once ensayos sobre la bistoria, Rioduero, Madrid, 1976).

117. SolÉ-Tura, Jordi: «La Qüestió de l'Estat i el concepte de nacionalitat», Taula de Canvi, núm. 1, septiembre-octubre 1976, págs. 5-20.

118. Sunkel, Oswaldo: «Capitalismo transnazionale e disintegrazione nazionale», Problemi del Socialismo, núms. 13-14, marzo-abril 1973.

119. SurAt'teau, Jean-René: La idea nacional. De la opresión a la liberación de los pueblos, Edicusa, Madrid, 1975.

120. TerraY, Emmanuel: «La idea de nación y las transformaciones del capitalismo», apéndice a: STALIN, Iosif: El marxismo y la cuestión nacional, Anagrama, Barcelona, 1977, págs. 151-173.

121. Torras, Joan: «La Nación, realidad histórica», Realidad, núm. 24, diciembre 1972, págs. $15-19$.

122. WIATR, J. J.: «Nation, patrie et coexistence pacifique», Tiers Monde, juliodiciembre 1968.

123. ZNANIECKI, Florian: «Las sociedades de cultura nacional y sus relaciones», Jornadas, núm. 24, 1944.

124. ZnANIECKI, Florian: Modern Nationalities, University of Illinois Press, Urbana (III.), 1952.

\subsection{Teoría del nacionalismo}

125. Astesano, Eduardo B.: Nacionalismo bistórico o materialismo bistórico, Pleamar, Buenos Aires, 1972.

126. BERLIN, Isaiah: «Sobre el nacionalismo», Trimestre Político, año 1 , núm. 1, julio-septiembre 1975, págs. 46-61.

127. Bermejo, Lito: «Las concepciones economicistas en el planteamiento de la cuestión nacional», Negaciones, núm. 3, mayo 1977, págs. 109-128.

128. Bullejos, José: El nacionalismo, Centro de Estudios y Documentación Sociales, México, 1964.

129. Calogeropoulos-Stratis, Spyros: Le droit des peuples à disposer d'euxmêmes, Bruylant, Bruselas, 1973.

130. CARLE, E.: Mancini e la teoria psicologica del sentimento nazionale, Roma, 1899.

131. CARr, E. H.: Nationalism and after, Macmillan, Londres, 1968. 
132. Costa Pinto, Luis A.: Nacionalismo y militarismo, Siglo XXI, México, 1969.

133. Cucurull, Félix: Consciència nacional $i$ alliberament, La Magrana, Barcelona, 1978.

134. DADRIAN, Vahakn N.: «The Bi-Polar Structure of Nationalism (A Conceptual Approach)», Revue Internationale de Sociologie, vol. 7, núm. 3, 1971.

135. Deutsch, Karl W.: El nacionalismo y sus alternativas, Paidos, Buenos Aires, 1971.

136. Durán y Ventosa, Luis: La esencia de los nacionalismos. Sus virtudes y sus peligros, Tor, Buenos Aires, 1939.

137. EmErson, Rupert: «Nacionalismo e desenvolvimiento politico», Revista Brasileira de Estudos Politicos, núm. 11, junio 1961, págs. 7-38.

138. Hayes, Carlton J. H.: El nacionalismo, una religión, Uteha, México, 1966.

139. GirardeT, Raoul: «Autour de l'Ideologie Nationaliste», Revue Française de Science Politique, vol. 15, núm. 3, junio 1965.

140. KedourIe, Elie: Nationalism, Hutchinson, Londres, 1978.

141. KIтsIKIs, Dimitri: «Le Nationalisme», Études Internationales, núm. 2, septiembre 1971.

142. KoHN, Hans: El nacionalismo. Su significado y su bistoria, Paidos, Buenos Aires, 1966.

143. KoHN, Hans: El pensamiento nacionalista en Estados Unidos, Troquel, Buenos Aires, 1966.

144. KoHN, Igor S.: «Le problème du caractère national», Ethno-Psychologie, año 29 , núms. 2-3, junio-septiembre 1974, págs. 193-223.

145. Lemberg, Eugen: «Nationalstaaten und ideologischen Systeme-Zum Selbstverständnis der mitteleuropäischen Völker im postnationalen Zeitalner», Der Staat, tomo 14, núm. 1, 1975, págs. 1-15.

146. Mancini, Pasquale Stanislao: Della nazionalità como fundamento del diritto delle genti, Turín, 1851.

147. Mancini, Pasquale Stanislao: Il principio di Nazionalità, Ed. La Voce, Roma, 1920.

148. Martindale, Don: «Sociologie de la notion de caractère national», Revue de Psychologie des Peuples, año 23, núm. 1, primer trimestre 1968, páginas $62-69$.

149. Michelat, Guy, y Hubert Thomas, Jean-Pierre: Dimensions des nationalismes, Enquête pa questionnaire (1962), Armand Colin, París, 1966.

150. Minogue, K. R.: Nacionalismo, Hormé, Buenos Aires, 1968.

151. Nairn, Tom: Nuevos nacionalismos en Europa, Península, Barcelona, 1979.

152. PlazA, Julio: «El Nacionalismo: orígenes y alternativas», Revista Juridica de la Facultad de Derecho y Ciencias Económicas, núm. 24, 1973.

153. Ploncaro D'Assac, J.: Doctrinas del nacionalismo, Acervo, Barcelona, 1971.

154. Poliakov, Léon: Le mytbe aryen. Essai sur les sources du racisme et des nationalismes, Calmann-Lévy, París, 1971.

155. Primo DE Rivera, José Antonio: «Ensayo sobre el nacionalismo», Obras completas, Publicaciones Españolas, Madrid, 1952, págs. 211-216.

156. Rocker, Rudolf: Nacionalismo y cultura, Madrid, 1977.

157. Ródenas, Pablo: «Hacia una teoría del nacionalismo», El Viejo Topo, número 29, febrero 1979 , págs. 9-13.

158. Royal Institute of InTERnational AffaIrs: Nationalism: $A$ Report by a Study Group of Members of the Royal Institute of International Affairs, Oxford University Press, Oxford, 1939.

159. Rubio García, Leandro: «El problema contemporáneo del nacionalismo», Revista de Política Internacional, núm. 10, enero-febrero 1969, págs. 51-63. 
160. SÁenz de Santamaría, Carlos: Qué son los nacionalismos, La Gaya Ciencia, Barcelona, 1976.

161. Shafer, Boyd Carlisle: Faces of Nationalism. New Realities and Old Myths, Harcourt Brace Jovanovich, Nueva York, 1972.

162. Smith, Anthony D.: Las teorias del nacionalismo, Península, Barcelona, 1976.

163. Tubella, I., y Vinyamata, E.: Diccionari del nacionalisme, Cuaderns d'Alliberament, Barcelona, 1979.

164. VEGA, Pedro de: «El carácter burgués de la ideología nacionalista», Sistema, núm. 16, enero 1977, págs. 51-63.

\subsection{Las regiones y el regionalismo}

165. Alvarez SACRISTÁn, Isidoro: Las regiones en pie, Editora Nacional, Madrid, 1974.

166. Ambrosini, Gaspare: «Stato ed autonomia regionale nel sistema della cessata monarchia austriaca e dell'attuale Reppublica spagnola», Il Circolo Giuridico, núm. 2, 1933.

167. Arcangelt, Fabio: «Rapporti centro periferia tra Regioni», Archivio di Studio Urbanistica Regionale, núm. 1, 1977, págs. 7-18.

168. BENEYTO, Juan: «Las comunicaciones sociales incoadoras de la regionalidad», Revista del Instituto de Ciencias Sociales, núm. 20, 1972, págs. 187-193.

169. BRUN, Charles: El Regionalismo, Francisco Beltrán, Madrid, 1918.

170. Busquets, Julio: «La región en Italia, Francia y España», Revista del Instituto de Ciencias Sociales, núms. 12-13, 1968-1969, págs. 129-157.

171. Claval, P., y Juillard, E.: Région et régionalisation dans la Géograpbie française et dans d'autres sciences sociales, Dalloz, París, 1967.

172. Charles-Brun, Jean: Le régionalisme, París, 1911.

173. Charles-Brun, Jean: Qu'est-ce que le régionalisme?, Lambert, París, 1936.

174. Diegues Junior, Manuel: Introducción a la Sociología regional, Universidad Autónoma Nacional de México, México, 1954.

175. Esteve Ríos, Manuel: «De la nacionalización a la regionalización», Información Comercial Española, núms. 417-418, 1968, págs. 87-90.

176. Fernández, Tomás Ramón: «Las autonomías regionales. Tendencias europeas», Civitas, Revista Española de Derecho Administrativo, núm. 10, julio-septiembre 1976, págs. 431-449.

177. FERRANDo, Juan: «El Estado regional como realidad jurídica independiente», Revista de Estudios Políticos, núms. 129-130, mayo-agosto 1963, páginas 75-119.

178. Ferrando, Juan: Formas de Estado desde la perspectiva regional, Instituto de Estudios Políticos, Madrid, 1965.

179. Ferrando, Juan: «Aproximaciones al concepto de región», Revista Española de la Opinión Pública, núm. 38, octubre-diciembre 1974.

180. Ferrando, Juan: «La región y el Estado regional», Revista Española de la Opinión Pública, núm. 47, enero-marzo 1977, págs. 7-55.

181. Ferrando, Juan: «El regionalismo en Europa», Revista de Estudios Políticos, núm. 216, noviembre-diciembre 1977, págs. 9-56.

182. Flour, Yvonne: «Regionalismo y unidad nacional», Verbo, núms. 135-136, mayo-julio 1975 , págs. $723-745$.

183. FonT I SAGUE, N.: Estudi sobre el regionalisme, La Estampa, Barcelona, 1894. 
184. Garrido Falla, Fernando: «La regionalización como fórmula descentralizadora», Documentación Jurídica, núm. 13, enero-marzo, 1977, págs. 29-42.

185. Gaudemet, Paul Marie: «Les problèmes financiers de la régionalisation», en GaUdemet, Paul Marie (dir.): Les aspects financiers de la régionalisation en Europe, Notes et Etudes Documentaires, París, 1974, págs. 7-17.

186. Gravier, F.: La question régionale, París, 1970.

187. INTERNATIONAL UNION OF Local AUTHORITIES: Regional planning and government in Europe, The Hague, 1971.

188. Holland, Stuart: The Regional Problem, Macmillan, Londres, 1978.

189. LAMBRECHTS, V.: «Régionalisation et administration: consequences et perspectives», Revue Internationale des Sciences Administratives, vol. 39, número 3,1973 , págs. $271-287$.

190. Larumbe, Pedro María: La región. Aspectos administrativos, Montecorvo, Madrid, 1973.

191. LARUMBE, Pedro María: «Hacia una administración regional como solución», Revista de Estudios Sociales, núms. 21-22, septiembre-diciembre 1977/enero-abril 1978, págs. 43-64.

192. LópEz-ARANGUREN, Eduardo: «Subdesarrollo regional, colonialismo interior y dependencia», Sistema, núm. 16, enero 1977, págs. 65-75.

193. MaÑE y Flaquer, Juan: El regionalismo, Imprenta Barcelonesa, Barcelona, 1887.

194. Marco, Luis: Regionalismo y dependencia, Ayuso, Madrid, 1977.

195. Martínez DE LA PEÑa, Diego: «La responsabilidad política en la región: el control del Gobierno por la Asamblea», en Ramírez, Manuel (ed.): El control parlamentario del Gobierno en las democracias pluralistas (el proceso constitucional español), Labor, Barcelona, 1978, págs. 327-341.

196. Massart-Pierard, Françoise: Pour une doctrine de la région en Europe, Centre d'études européens, Bruselas-Lovaina, 1974.

197. MeIlán, José Luis: «La cuestión regional», Homenaje a Segismundo RoyoVillanova, Ed. Moneda y Crédito, Madrid, 1977, págs. 591-628.

198. Pereira, Aureliano: El regionalismo, Imprenta Luis Tasso, Barcelona, 1887.

199. Pérez Díaz, Pedro: La cuestión regional y la autonomia, Hijos de J. A. García, Madrid, 1908.

200. Pérez Moreno, Alfonso: «Utbanismo y desarrollo regional: contenido del nuevo regionalismo», Civitas. Revista Española de Derecho Administrativo, núm. 8, enero-marzo 1976.

201. PÉREZ SÁDABA, Vicente: Regiones naturales y regionalismo, Zyx, Madrid, 1968.

202. Petrella, Ricardo (ed.): Le développement régional en Europe, Mouton, París-La Haya, 1971.

203. Rubiales, Amparo: La región: bistoria y realidad, Instituto García Oviedo, Sevilla, 1973.

204. SÁEnz De BuRuaga, Gonzalo: Ordenación del territorio. El caso del País Vasco y su zona de influencia, Guadiana, Madrid, 1969.

205. Stmón DE Tobalina, Juan Luis de: «La región, problema ineludible», Razón y $\mathrm{Fe}$, núm. 914, marzo 1974, págs. 213-224.

206. Sturzo, L.: La regione nella nazione, Roma, 1947.

207. Trujillo García, Antonio: El regionalismo, Cámara Oficial de Comercio e Industria de la Provincia de Jaén, Jaén, 1977.

208. VIER, Charles-Louis: «Les aspects financiers de la politique régionale des Communautés européennes», en GAuDEMET, Paul Marie (dir.): Les aspects financiers de la régionalisation en Europe, Notes et Etudes Documentaires, París, 1974, págs. 84-97. 


\subsection{El marxismo y la cuestión nacional}

209. Autores varios: El marxismo y la cuestión nacional, Avance, Barcelona, 1976.

210. ÁbELláN, José Luis: «La "cuestión nacional' en el marxismo», Sistema, número 21, noviembre 1977, págs. 81-86.

211. AGNELLI, Arduino: «El socialismo y el problema de las nacionalidades en Otto Bauer», en: Zanardo, Aldo (dir.): Historia del marxismo contemporáneo, Avance, Barcelona, 1976, págs. 325-357.

212. Audet, Rosa María: Rosa Luxemburgo y la cuestión nacional, Anagrama, Barcelona, 1977.

213. BAUER, Otto: Die Nationalitätenfrage und die Sozialdemokratie, Volksbuchhandlung, Wien, 1907 (los capítulos 9, 10 y 30 se reproducen en la entrada número 209 de este repertorio, págs. 94-137).

214. BAUER, Otto: Die nationalitätenfrage, Wien, 1924 (edición ampliada de la anterior).

214. Bauer, Otto: «Observaciones sobre la cuestión de las nacionalidades», incluida en la entrada número 246 de este repertorio, págs. 172-185.

214. BAUER, Otto: «El obrero y la nación», incluido en la entrada número 246 de este repertorio, págs. 248-256.

215. BoERSner, Demetrio: Socialismo y Nacionalismo, Instituto de Estudios Políticos de la Universidad Central de Venezuela, Caracas, 1965.

216. Bloom, S. F.: El mundo de las naciones. El problema nacional en Marx, Siglo XXI, Madrid, 1976.

217. Borojov, Don ber; IAARI, Meir, y Najum, Daniel ben: La cuestión nacional. Nación. Pueblo. Lucha de clases. Liberación nacional. Antiimperalismo. Sionismo-socialismo, Ediciones Vascas Argitaletxea, San Sebastián, 1979.

218. Bourdet, Yvon (ed.): Marxistas e nacions en lucha, Fédorop-Minorités nationales, Lyon, 1976.

219. Bourdet, Yvon: «Proletariado universal y culturas nacionales», en el vol col. Comunistas y/o nacionalistas, Anagrama, Barcelona, 1977, págs. 117-153.

220. Carrere D'EnCAUSSE, Hélène: «Comunismo y nacionalismo», en la obra citada en la entrada precedente, págs. 7-58.

221. Carrere D'Encausse, Hélène: «Unidad proletaria y diversidad nacional. Lenin y la teoría de la autodeterminación», en el vol. cit. en la entrada núto 219 , págs. $59-116$.

222. Davis, Horace B.: Nacionalismo y socialismo, Península, Barcelona, 1972.

223. Dayan-Herzbrun, Sonia: «Nationalisme et socialisme chez Ferdinand Lassalle, L’bomme et la societé, núm. 5, 1967.

224. Enea Spilimbergo, Jorge: La cuestión nacional en Marx, Octubre, Buenos Aires, 1974.

225. ForCADELL, Carlos: «El problema nacional y la guerra en el pensamiento marxista anterior a 1914», Cuadernos Aragoneses de Economía, núm. 2, 1977 1978, págs. 39-49.

226. Gárate, G.: «Marx y los nacionalismos», Estudios de Deusto, núm. 43, mayo-agosto 1971 , págs. $235-263$.

227. Haupt, Georges, y Lowy, Michael: Els marxistes y la qüestió nacional (1848-1914), La Magrana, Barcelona, 1978.

228. HobSBAWM, Eric: «Marxismo, nacionalismo e independentismo», Zona Abierta, núm. 19, marzo-abril 1979, págs. 89-111.

229. KAUSTKY, Karl: La nacionalidad moderna, incluido en la entrada número 246 
de este repertorio y, parcialmente, en la entrada número 209, págs. 108-139 (vol. $1 .^{\circ}$ ) y $50-63$.

230. KAUSTKY, Karl: Las tareas nacionales de los socialistas entre los eslavos de los Balcanes, incluido parcialmente en la entrada número 209 de este repertorio, págs. 80-85.

231. KAUSTKY, Karl: Nacionalidad e internacionalismo, incluido en la entrada número 246 de este repertorio y parcialmente en la entrada número 209, páginas $121-167$ (vol. $2^{\circ}$ ) y 64-79.

232. KAUSTKY Karl: La autodeterminación de las naciones, incluido en la entrada número 209, págs. 86-93.

233. LENIN, Vladimir Ilicht: Problemas de política nacional e internacionalismo proletario, Progreso, Moscú, 1966.

234. LENIN, Vladimir Ilicht: «Sobre el derecho de las naciones a la autodeterminación», Obras escogidas, Progreso, Moscú, 1966, tomo 1., págs. 613-668, incluido en la entrada número 209, págs. 213-258.

235. LENIN, Vladimir Ilicht: «El orgullo nacional de los grandes rusos», Obras escogidas, Progreso, Moscú, 1966, tomo 1.․, págs. 678-681.

236. LENIN, Vladimir Ilicht: «La consigna de los Estados Unidos de Europa», Obras escogidas, Progreso, Moscú, 1966, tomo $1 .^{\circ}$, págs. 682-685.

237. LENIN, Vladimir Ilicht: Caricatura del marxismo y economicismo imperialista, incluido en la entrada 209, págs. 259-269.

238. LENIN, Vladimir Ilicht: La revolución socialista y el derecho de las naciones a la autodeterminación, incluido en la entrada 209, págs. 270-272.

239. LenIN, Vladimir Ilicht: «Acerca del problema de las nacionalidades y la autonomización», Obras escogidas, Progreso, Moscú, 1966, tomo 3., páginas $773-778$.

240. LEON, A.: La conception materialiste de la question juive, Etudes et Documentation Internationales, París, 1968 (revisión y presentación por Maxime Rodinson. Textos complementarios de Leon Trostki, Isaac Deustcher y E. Germain).

241. Levrero, Renato: Nación, metrópoli y colonias en Marx y Engels, Anagrama, Barcelona, 1975.

242. LowY, Michael: «Los marxistas y la cuestión nacional», Ideología y Sociedad, núm. 20, enero-marzo 1977, págs. 9-30.

243. Luxemburg, Rosa: Textos sobre la cuestión nacional, Ediciones de la Torre, Madrid 1977 (notas y compilación de Manuel P. Izquierdo).

244. LuXemburg, Rosa: La cuestión nacional y el desarrollo capitalista, Cuadernos de Pasado y Presente, México, 1978.

245. LLuCH, Ernest: «Trotski i la qüestió nacional catalana en els anys 30», Revista de Catalunya, núm. 106, 1967, págs. 59-62.

246. Marmora, Leopoldo (ed.): La Segunda Internacional y el problema nacional y colonial. Bernstein, Belfort Bax, Kaustky, Renner, Calwer, Bauer, Strasser, Pannekoek, Cuadernos de Pasado y Presente, México, 1978, 2 vols.

247. MarX, Karl, y Engels, Friedrich: La cuestión nacional y la formación de los Estados, Cuadernos de Pasado y Presente, México, 1978.

248. MARX, Karl, y ENGELS, Friedrich: Imperio y colonia. Escritos sobre Irlanda, Cuadernos de Pasado y Presente, México, 1978.

249. Momsen, Hans: Die Sozialdemokratie und die Nationalitätenfrage im Habsburgischen Vielvölkerstaat, Europa Verlag, Wien, 1963.

250. Nin, Andreu: Els moviments d'emancipació nacional, Edicions Catalanes de Paris, París, 1970.

251. Pannekoex, Anton: Lucba de clases y nación, incluido en la entrada número 246 , tomo $2 .^{\circ}$, págs. 259-304. 
252. Renner, Karl: Estado y Nación. Acerca de la cuestión austríaca de las nacionalidades (Estudio de Derecho público sobre los posibles principios de solución y los presupuestos jurídicos de una ley de las nacionalidades), incluido en las entradas 209 y 246, págs. 140-158 y $145-180$ respectivamente (seudónimo: Synoptikus).

253. ReNneR, Karl: Der kampf der österreichischen Nationen um den Staat, Leipzig-Wien, 1902 (seudónimo: Rudolf Springer).

254. Renner, Karl: Was ist nationale Autonomie? Was ist soziale Verwaltung Einfübrung in die nationale Frage und Erläuterung der Grundsätze des nationalen Programms der Sozialdemokratie, Wien, 1913.

255. Renner, Karl: Die Nation: Mytbos und Wirklicbleit, Wien, 1964.

256. Ribeyrioux, M.: «Jaurés et la nation», Actes du colloque Jaurés et la Nation, Association des Publications de la Faculté des Lettres et Sciences Humaines, Toulouse, 1965.

257. Riвó, Rafael: «Marxismo, catecismo y cuestión nacional», prólogo a STALiN, Iosif: El marxismo y la cuestión nacional, Anagrama, Barcelona, 1977, páginas 7-31.

258. RoDInSoN, Maxime: «Sobre la teoría marxista de la nación», apéndice a: StalIn, Iosif: El marxismo y la cuestión nacional, Anagrama, Barcelona, 1977, págs. 123-149.

259. SCHLESINGER, Rudolf: La Internacional Comunista y el problema colonial, Cuadernos de Pasado y Presente, Córdoba (Argentina), 1974.

260. SorozÁBAL, Juan José: «Algunos materiales sobre el pensamiento socialista ante el problema nacional», Revista Internacional de Sociología, núms. 3-4, 2.a época, julio-diciembre 1972, págs. 111-130.

261. Spillingnergo, J. E.: Marx y la revolución nacional, Coyoacán, México.

262. Stalin, Iosif: El marxismo y la cuestión nacional, Fundamentos, Madrid, 1976 (también Anagrama, Barcelona, 1977; incluido en la entrada número 209 , págs. 275-295).

263. StILlig, Jürgen: «Das problem Elsass-Lothringen und die Sozialistische Internationale im Jahr 1917», Vierteljabrsbefte für Zeit-Gescbicbte, año 22, núm. 4, 1974, págs. 62-76.

264. Strasser, Josef: El obrero y la nación, incluido en la entrada número 246, tomo $2 .^{\circ}$, págs. 189.256 .

265. WEHLER, Hans-Ulrich: Sozialdemokratie und Nationalstaat. Nationalitätenfrage im Deutscbland, 1840-1914, Vaudeunhock-Ruprecht, Gotinga, 1971.

\section{ESTUdIOS REgIONALES, NACIONALES, CONTINENTALES}

\subsection{Estudios por continentes. Africa}

266. Bonnafe, P.: Les Nationalismes africains, Fondation Nationale des Sciences Politiques, París, 1962.

267. Currie, David P. (ed.): Federalism and the New Nations of Africa, The University of Chicago Press, Chicago, 1964.

268. Dietmann, Alfonso: «Nacionalismo y pluralismo en Africa Negra», Politeia, núm. 4, 1975, págs. 175-238.

269. Hazoume, Guy Landri: Ideologies tribalistes et nation en Afrique, Editions Présence Africaine, París, 1972.

270. JulIEN, Charles-André: L'Afrique du Nord en marcbe: nationalismes musulmans et souveranité française, Julliard, París, 1972. 
271. Markov, Walter: «La Nation dans l'Afrique Tropicale: Notion et Structure», L'Homme et la Societé, núm. 2, 1966.

272. Mills, Atta: «Régions et problèmes de planification régionale dans le contexte des économies africaines», Espaces et Societés, núms. 10-11, octubre 1973/febrero 1974.

273. RICHARDS, Audrey I.: The Multicultural States of East Africa, McGillQueen's University Press, Montreal, 1969.

274. SAvonNET-GuYot, Claudette: «Espace politique et paysannats d'Afrique noir. A propos des difficultés de la construction nationale en Afrique noir», L'Homme et la Societé, núm. 27, enero-marzo 1973, págs. 149-167.

275. Smock, David R., y Bentsi-Enchill, Kwamene (eds.): The Search for National Integration in Africa, Free Press-Collier-Macmillan, Nueva York-Londres, 1975.

\subsection{Estudios por continentes. América}

276. FIX-Zamudio, Héctor (coord.): Los sistemas federales del continente americano, Universidad Nacional Autónoma de México, Fondo de Cultura Económica, México, 1972.

277. WhITAKeR, Arthur P.: «The New Nationalism in Latin America», The Review of Politics, vol. 35, núm. 1, January, 1973, págs. 77-90.

\subsection{Estudios por áreas. Nacionalismo árabe}

278. AmIN, Samir: La nation árabe. Nationalisme et luttes de classes, Minuit, París, 1976.

279. Dawn, Clarence E.: From Ottomanism to Arabism. Essays on the origins of Arab nationalism, University of Illinois Press, Urbana (III.), 1973.

280. ZeIne Nour-uD-DIN: The Emergence of Arab Nationalism. With a BachGround Study of Arab Turkish Relations in the Near East, Caravan Books, Nueva York, 1973.

\subsection{Estudios por áreas. Estados socialistas}

281. Carrere D'Encausse, Hèléne: «Les realités contra l'ideologie. Classes et nations dans 1'Europe socialiste», Revue Française de Science Politique, volumen 19, núm. 1, febrero 1969.

282. García Allvarez, Manuel B.: «La cuestión de las nacionalidades en las Constituciones socialistas», Revista de la Fecultad de Derecho de la Universidad Complutense de Madrid, núms. 50-51, 1974, págs. 479-498.

283. KING, R. R.: Minorities under Communism. Nationalities as a Source of Tension among Balkan Communists States, Cambridge (Mass.), 1973.

\subsection{República Federal de Alemania}

284. Cabanas, Marcelino:' «Alemania. La constitución de los 'Länder'», Información Jurídica, núms. 50-51, julio-agosto 1947, págs. 150-153.

285. ConzAT'T, Alessandro: «La riforma territoriale in Germania», Amministrare, núm. 31, septiembre 1970, págs. 101-112. 
286. Charbonneau, Simon: «Du féderalisme au régionalisme, étude rélative aux mécanismes financiers de la centralisation en Alemagne féderale», Revue d'Allemagne, 1972, págs. 791-822.

287. Feuchte, Paul: «Die bundesstaatliche Zusammenarbeit in der Verfassungswirklichkeit der Bundestepublik Deutschland», Archiv des öffentlichen Rechts, tomo 98, fasc. 4, 1973, págs. 473-528.

288. Foelz-Schroeter, Marie-Elise: Föderalistiche Politik und nationale Repräsentation 1945-1947. Westdeustche Länderregierungen, zonale Börokratien und politische Parteien im Widerstreit, Deutsche Verlags-Ansthalt, Stuttgart, 1974.

289. KLEIN, F.: «Die Regelung der Gemeinschaftsaufgaben von Bund und Ländern im Grundgesetz», Der Staat, tomo 11, fasc. 3, 1972, págs. 289-312.

290. KRAEHE, Rainer: «Les aspects financiers de la régionalisation en République Féderale d'Allemagne», en: GaUdEMET, Paul Marie (dir.): Les aspects financiers de la régionalisation en Europe, Notes et Études Documentaires, París, 1974, págs. 70-82.

291. KunZE, Renate: Kooperativer Föderalismus in der Bundesrepublik, Gustav Fischer Verlag, Stuttgart, 1968.

292. LAUFER, Heinz: Der Föderalismus in der Bundesrepublik Deutscbland, Stuttgart, 1974.

293. LeHMBRUCH, Gerhard: «Party and Federation in Germany: A Development Dilemma», Government and Opposition, vol. 13, núm. 2, primavera 1977, págs. 151-177.

294. Massagrande, Danilo L.: «Problemi etnici e rapporti politici nella Ungheria occidentale tedesca: Giugno-Settembre 1919», Il Politico, año 41, núm. 2, 1976.

295. MÜNCH, Fritz: Die Bundesregierung, Alfred Metzner Verlag, Francfort am Mein, 1954.

296. NoHLEN, Dieter: «Sistema federal y sistema de partidos políticos. Algunas anotaciones sobre el desarrollo del federalismo en la República Federal de Alemania», Revista de Estudios Politicos, núm. 4, 2. a época, julio-agosto 1978, págs. 149-154.

297. Röper, Erich: «Aspekte der Neugliederung des Bundesgebiets», Der Staat, tomo 14, fasc. 3, 1975, págs. 305-346.

298. RuMPLER, Helmutt: «Föderalismus als Problem der deutschen Verfassungsgeschichte des 19. Jahrhunderts - 1815-1871», Der Staat, vol. 16, fasc. 2, 1977, págs. 215-228.

299. SANvITr, Giuseppe: "Il problema dell'autonomia regionale in Germania dopo la recente istituzionalizzazione della cooperazione fra i 'Länder'», Rivista Trimestrale di Diritto Pubblico, año 26, núm. 3, 1976.

300. SCHAFER, Friedrich: Los aspectos del sistema federalista en la República Federal de Alemania, Inter-Nationes, Bonn-Bad Godesberg, 1975.

301. SCHEUNER, Ulrich: «Wandlugen im Föderalismus der Bundesrepublik Deutschland», Die öffentliche Verwaltung, 1966.

302. Schоlz, Gerhard: «Kurt Eisners Föderalismus», Politische Studien, número 177,1968 , págs. $46-60$.

\subsection{Argentina}

303. BECERRA, Guillermo: «Reestructuración de la forma federal argentina», Revista del Instituto de Ciencias Sociales, núm. 10, 1967.

304. Frías, Pedro J.: «Federalismo y planeamiento en la Argentina», Revista del Instituto de Ciencias Sociales, núm. 18, 1971. 
305. FRías, Pedro J.: «Nación y provincias en el federalismo argentino», Boletín de la Facultad de Derecho y Ciencias Sociales, enero-diciembre, 1973.

\subsection{Australia}

306. «Australia. El sistema de Gobierno», Información Jurídica, núm. 94, marzo 1951, págs. 188-194.

307. WARD, R. C.: «Federalism and the Northern territory», Australian Quarterly, septiembre 1963, págs. 14-22.

308. WARD, R. C.: «Federalism and the Northern territory since 1947», Australian Quarterly, diciembre 1963, págs. 39-50.

\subsection{Austria}

309. Esterbauer, Fried: «Aktuelle probleme des Föderalismus in Österreich», Der Staat, tomo 12, fasc. 4, 1973, págs. 499-523.

310. KreIssLer, Felix: «La difficile naissance d'un sentiment national: 1'Autriche», Etbonopsychologie, año 28, núm. 4, 1973, págs. 347-377.

311. Melichar, Erwin: «Entwicklungstendenzen des österreichisnen Föderalismus», Osterreichische Zeitscbrift för öffentlicbes Recbt, tomo 17, fasc. 3-4, 1967, págs. 214-269.

312. OEHLINGER, Theo: «Die föderative Verfassung Osterreichs», Die öffentliche Verwaltung, vol. 31, 1978, págs. 897-906.

\subsection{Bélgica}

313. Armstrong Kelly, George: «Belgium. New Nationalism in an Old World», Comparative Politics, vol. 1, núm. 3, abril 1969, págs. 343-365.

314. BuCH, Henri: «La planification regionale et l'administration regionale en Belgique», Revista del Instituto de Ciencias Sociales, núm. 18, 1971.

315. Deschamps, J. F.: «Le problème institutionnel belge: les questions préalables», Dossiers de l'Action sociale catbolique, septiembre 1963, páginas 589-598.

316. Destree, U., y Dehousse, J. M.: «La répartition des compétences dans les projets fédéralistes des socialistes wallons», Res Publica, vol. 5, núm. 4, 1963, págs. 334-359.

317. Fischer, A.; Mitchell, J. D. B.; Ferrari, P.; Vier, C. L., y Moureau, Léon: Études sur le régionalisme en Belgique et à l'étranger, E. Bruylant, Bruselas, 1973.

318. HARMEL, Pierre: «Les problèmes wallons et flamands et la réforme des institutions», Revue Nouvelle, núm. 15, enero 1964, págs. 45-59.

319. Herremans, M. P.: «Le contentieux Flamands-Wallons», Socialisme, marzo 1963 , págs. 184-205.

320. Herremans, M. P.: «Le fait bruxellois», Courrier bebdomadaire, 24 diciembre 1963/3-10 enero 1964, págs. 22-47.

321. Mols, R.: «Le problème bruxellois: le 'plus grand Bruxelles'», Revue Nouvelle, marzo 1964, págs. 249-269.

322. WIGNY, Pierre: «La loi du $1 .^{\mathrm{e}}$ aoùt 1974 , créant des institions regionales à titre prèparatoire à l'application de l'article 107 quater de la Constitution", Journal des Tribunaux, núm. 4.888, noviembre 1974. 


\subsection{Brasil}

323. Bonavides, Paulo: «O planejamento e os organismos regionais como preparação a um federalismo das regioes (a experiencia brasileira», Revista del Instituto de Ciencias Sociales, núm. 18, 1971.

324. Brasileiro, Ana Maria: «O federalismo corporativo», Revista Brasileira de Estudos Politicos, núm. 39, julio 1974, págs. 83-128.

325. Cavalcanti, A.: «Govêrno e administração do Estado de Guanabara», Revista do Servico Publico, enero-marzo 1961, págs. 6-40.

326. TrigueIro, Oswaldo: «A crise do federalismo, Revista Brasileira de Estudios Políticos, núm. 11, junio 1961, págs. 39-56.

\subsection{Camerin}

327. «Le budget fédéral et les budgets des Etats au Cameroun», Etudes et statistiques. Bulletin Mensuel, Cameroun, Afrique équatoriel. Banque Centrale octubre 1962, págs. 415-424.

328. Benjamin, Jacques: Les Camarounais occidentaux. La minorité dans un Etat bicomunitaire, Presses de l'Université de Montreal, Montreal, 1972.

329. Le Vine, Victor T.: The Cameroun Federal Republic, Cornell University Press, Ithaca, 1971.

330. Rubin, Neville: Cameroun: An Atrican Federation, Praeger, Nueva York, 1971.

\subsection{Canadá}

331. Aubert de LA Rue, P.: «Le Quebec et l'avenir du Canada», Politique Etrangère, núms. 4-5, 1963, págs. 330-346.

332. Blanchard, R.: «Les mouvements d'indépendence au Canada français», Revue des travaux de l'Academie des sciences morales et politiques, año 116, 4. ${ }^{a}$ serie, primer trimestre 1963, págs. 209-222.

333. Bonenfant, J. C.: «Le bicaméralisme dans le Quebec», Canadian Journal of Economics and Political Science, noviembre 1963, págs. 495-504.

334. Bourque, Gilles, y Laurin-Frenet"re, Nicole: «Classes sociales et idéologies nationalistes au Quebec, 1760-1970», L'Homme et la Societé, núms. 24-25, abril-septiembre 1972.

335. Cunneo, Carl J., y Curtis, James E.: «Quebec Separatism: An Analysis of Determinants within Social-Class Levels», The Canadian Review of Sociology and Antbropology, vol. 11, núm. 1, febrero 1974.

336. DAvIS, Georges: «El federalismo canadiense», Información Jurídica, números 174-175, noviembre-diciembre 1957.

337. Kuruvilla, P. K.: «The Problem of Bilingualism in the Canadian Public Service», Res Publica, vol. 14, núm. 4, 1972, págs. 785-802.

338. LANPHIER, C. M., y MoRrIs, R. N.: «Structural Aspects of Differences in Income between Anglophones and Francophones», The Canadian Review of Sociology and Antbropology, vol. 11, núm. 1, febrero 1974.

339. McWHINNEX, Edward: «French-Canadian Nationalism and Separatism and Contemporary Canadian Federalism», Jabrbuch des öffentlicben Rechts, tomo 21,1972 , págs. $571-590$.

340. McWhInNEY, Edward: «Constitutional Solutions for the Racial-linguistic 
crisis in French-Canada», Jabrbuch des öffentlichen Recbts, tomo 23, 1974, págs. 489-504.

341. Morin, Claude: Le pouvoir québécois... en négotiation, Editions du Boreal Express, Montreal, 1972.

342. Morin, Claude: Le combat québécois, Editions du Boreal Express, Montreal, 1973.

343. Parenteau, R.: «Les problèmes du développement régional dans un Etat fédératif: l'expérience canadienne», Revue d'Economie Politique, marzo-abril 1963, págs. 161-222.

344. Prevost, J. P.: La crise du fédéralisme canadien, Presses Universitaires de France, París, 1972.

\subsection{Cbina}

345. BERGERE, Marie-Claire: «L'influence du modèle soviétique sur la politique des minorités nationales en Chine», Revue Française de Science Politique, vol. 29, núm. 3, junio 1979 , págs. 402-425.

346. Dreyer, June T.: Cbina's forty millions. Minority nationalities and national integration in the People's Republic of China, Harvard University Press, Cambridge (Mass.), 1976.

347. MCCoLL, R. W.: «Development of supraprovincial administrative regions in comunist China, 1949-1960», Pacific Viewpoint, marzo, 1963, págs. 53-64.

348. Moseley, G.: The Party and the National Question in China, The M.I.T. Press, Cambridge (Mass.), 1966.

349. Patterson, G. N.: «Recent Chinese Policies in Tibet and toward the Himalayan Border States», The Cbina Quarterly, núm. 12, octubre-diciembre 1962, págs. 191-202.

350. Schwarz, Henry G.: «Communist Language Policies for China's Ethnic Minorities: the First Decade», The Cbina Quarterly, núm. 12, octubre-diciembre 1962, págs. 170-182.

351. WheELER, G.: «Sin-Kiang and the Soviet Union», The Cbina Quarterly, núm. 16, octubre-diciembre 1963, págs. 56-61.

\subsection{Estados Unidos}

352. BAKER, Stewart A.: «Federalism and the Eleventh Amendment», University of Cincinnati Law Review, núm. 2, 1972.

353. BeER, Samuel H.: «Federalism, Nationalism, and Democracy in America», The American Political Science Review, vol. 72, núm. 1, marzo 1978, páginas 9-21.

354. BernsteIn, Blanche: «The State and Social Welfare», Proceedings of the Academy of Political Science, vol. 31, núm. 3, mayo 1974, págs. 146-160.

355. CoHEN, Jacob, y Grodzins, Morton: «How Much Economic Sharing in American Federalism?», The American Political Science Review, vol. 57, núm. 1, marzo 1963, págs. 5-23.

356. Colman, Williams G.: «The Changing Role of the States in the Federal System», Proceedings of the Academy of Political Science, vol. 31, núm. 3, mayo 1974, págs. 73-84.

357. CrichField, Brevard, y Clyde-Reeves, H.: «Intergovernmental Relations: A View from the States», The Annals of the American Academy of Political and Social Science, vol. 416, noviembre 1974, págs. 99-107.

358. DerthICK, Martha: Between State and Nation: Regional Organizations of the United States, The Brookings Institution, Washington, D. C., 1974. 
359. DorSEN, Norman: «The National No-Fault Motor Vehicles Insurance Act: A Problem in Federalism», New York University Law Review, abril 1974.

360. FrIEDRICH, Carl J.: «Origin and Development of the Concept of Federalism in the United States», Jabrbuch des öffentlichen Recbts der Gegenwart, 1960.

361. GoldBerg, Delphis C.: «Intergovenmental Relations: From the Legislative Perspective», The Annals of the American Academy of Political and Social Science, vol. 416, noviembre 1974, págs. 52-66.

362. GRAvEs, Thomas J.: «IGR and the Executive Branch: the New Federalism», The Annals of the American Academy of Political and Social Science, volumen 416, noviembre 1974, págs. 40-51.

363. Guedon, Matie-José: «Etats-Unis. L'inadaptation du fédéralisme aux problèmes de l'urbanisation», Revue de Droit Public, núm. 3, 1973, págs. 739-776.

364. HaIder, Donald H.: «The State and the Federal Government», Proceedings of the Academy of Political Science, vol. 31, núm. 3, mayo 1974, páginas 85-95.

365. HILF, Meinhard: «Das 10. Amendment im Wandel des Föderalismus in der Vereinigten Staaten von Amerika», Jabrbucb des öfentlicben Rechts, t. 22, 1973, págs. 595-619.

366. Jones, Charles O., y Thomas, Robert D. (eds.): Public Policy in Making in a Federal System, Sage, Londres, 1976.

367. La Pergola, Antonio: Residui «contrattualistici» e struttura federale nell'ordinamento degli Stati Uniti, Milán, 1969.

368. Newton, Robert D.: «Administrative Federalism», Public Administration Review, vol. 38, núm. 3, mayo-junio 1978, págs. 252-256.

369. OsterweIs, Rollin G.: Romanticism and Nationalism in the Old South, Louisiana State University Press, Baton Rouge (La), 1967.

370. Reagan, Michael D.: The New Federalism, Oxford University Press, Nueva York, 1972.

371. Rockefeller, Nelson: The Future of Federalism, Harvard University Press, Cambridge (Mass.), 1962.

372. SEIDman, Harold: Politics, Position and Power. The Dynamics of Federal Organization, Oxford University Press, Nueva York, 1970.

373. Sharkansky, Ira: Regionalism in American Politics, Bobbs-Merrill, Nueva York, 1970.

374. Sharkansky, Ira: The Maligned States: Policy Accomplishments, Problems and Opportunities, McGraw Hill, Nueva York, 1972.

375. SundQuIST, James L., y Davis, David W.: Making Federalism Work, The Brookings Institution, Washington, D. C., 1969.

376. WELCH, Susan E.: «Interstate Compacts and National Integration: An Empirical Assesment of Some Trends», The Western Political Quarterly, vol. 26, núm. 3, septiembre 1973, págs. 475-484.

377. WRIGHT, Deil S.: Understanding Intergovernmental Relations: Public Policy and Participants Perspectives in Local, State, and National Governments, Duxbury Press, North Scituate (Mass.), 1978.

378. WRIGHT, Deil S.: «Del federalismo a las relaciones intergubernamentales en los Estados Unidos de América: una nueva perspectiva de la actuación recíproca entre el gobierno nacional, estatal y local», Revista de Estudios Politicos, núm. 6, 2. época, noviembre-diciembre 1978, págs. 5-28.

379. YAARI, Arieh: «Assimilation versus diférentation. Le phénomene national aux Etats-Unis d'Amérique», L'Homme et la Societé, núm. 37-38, julio-diciembre 1975. 


\subsection{Francia}

380. Atelier Occitan: L'Occitanie. Realité d'bier et d'aujourd'bui, Notre Dame, Nimes, 1972.

381. Barral, Pierre: «Idéal et pratique du régionalisme dans le régime de Vichy», Revue Française de Science Politique, vol. 24, núm. 5, octubre 1974, págs. 911-939.

382. Barthelemy, Joseph: Provinces. Pour construir la France de demain, Grasset, París, 1941.

383. BERN, Philippe: «Les aspects financiers de la régionalisation en France», en GAUDEMET, Paul Marie (dir.): Les aspects financiers de la régionalisation en Europe.

384. BouRJol, Maurice: Les institutions regionales de 1789 à nos jours, BergerLevrault, París, 1969.

385. BourJol, Maurice: Région et Administration regionale, Berger-Levrault, $\mathrm{Pa}$ rís, 1970.

386. Brongniart, P.: La Région en France, Armand Colin, París, 1971.

387. Dayries, Jean-Jacques, y Dayries, Michele: La règionalisation, Presses Universitaires de France, París, 1978.

388. Det'Ton, P.: L'administration régionale et locale en France, Presses Universitaires de France, París, 1953.

389. Dulong, Ranaud: «La crise du rapport Etat/societé locale vue au travers de la politique régionale», en Poulantzas, Nicos (ed.): La crise de l'Etat, Presses Universitaires de France, París, 1976, págs. 209-232.

390. Dulong, Ranaud: Les régiones, l'Etat et societé locale, Presses Universitaires de France, París, 1978.

391. DurRIEU, Yves: L'impossible régionalisation capitaliste. Témoignanes de Fos et du Languedoc, Anthropos, París, 1973.

392. Ferrari, P., y VIER, Ch.-L.: «La réforme régionale. Loi du 5 juillet 1972 portant création et organisation des régions», L'actualité juridique: Droit ad. ministratif, núm. 10, 1972, págs. 491-511.

393. FLORY, Th.: Le mouvement régionaliste français, Presses Universitaires de France, París, 1966.

394. Fouere, Yann: La Bretagne écartelée (1938-1948), Nouvelles editions latines, Paris, 1966.

395. Fougeyrollas, Pierre: «Question nationale et lutte des classes dans la France de demain», Les Temps Modernes, núms. 324-326, 1973, págs. 509-532.

396. GICQUEL, Yvonning: Le comité consultif de Bretagne: un essai de décentralisation au milieu du XIXe siècle, Simon, Rennes, 1961.

397. Grordan, Henri: «Occitanie: langue, culture, lutte de classes», L'Homme et la Societé, núm. 28, abril-junio 1973, págs. 133-145.

398. Gremion, Pierre: La mise en place des institutions régionales, París, 1965.

399. Gremion, Pierre: «La théorie de l'apprentissage institutionnel et la régionalisation du cinquiéme plan», Revue Française de Science Politique, vol. 23, núm. 2, abril 1973, págs. 305-320.

400. Gremion, Pierre, y Worms, Jean-Paul: Les institutions régionales et la société locale, París, 1968.

401. Hourtice, Jean: «La loi du 7 juillet 1972 portant création et réorganisation des régions», La Revue Administrative, núm. 150, 1972, págs. 635-639.

402. LAFONT, Robert: La revolución regionalista, Ariel, Barcelona, 1971.

403. Larumbe, Pedro María: «Informe sobre el Proyecto francés de Ley regio- 
nal, Revista de Administración Pública, núm. 68, mayo-agosto 1972, páginas $405-447$.

404. Larumbe, Pedro María: «La regionalización francesa: la ley de 5 de julio de 1972», Revista de Administración Pública, núm. 69, septiembre-diciembre 1972, págs. 409-440.

405. Larumbe, Pedro María: «La regionalización francesa», Anuario de Derecho Administrativo, núm. 1, 1975-1976.

406. LARZAC, Jean (dir.): Le petit livre de l'Occitanie, Maspero, París, 1972.

407. LESPES, Jean: Les régions administratives et la nouvelle économie française: préfets régionaux et intendents des affaires économiques, Sirey, París, 1942.

408. Liet-VAux, Georges: Le régionalisme constitutionnel, Durand-Auzias, París, 1943.

409. MeILÁn, José Luis: Reformas de los Departamentos y Regiones de Francia, Centro de Formación y Perfeccionamiento de Funcionarios, Madrid, 1964.

410. MeNY, Ives: Centralisation et décentralisation dans le debat politique française (1945-1969), Librairie Génerale des Droit et de la Jurisprudence, París, 1974.

411. Muzellec, Raymond: «La consultation pré-réferendaire de septembre 1968 en Bretagne sur la régionalisation», Revue de Droit Public, 1973, páginas 657-710.

412. NETTI, Claudio: «La questione regionale in Francia», Rivista Trimestrale di Diritto Pubblico, año 26, núm. 4, 1975.

413. PISANI, Edgard: La région... pour quoi faire?, París, 1969.

414. Servan-SchreIBer, Jean-Jacques: $E l$ poder regional, Dopesa, Barcelona, 1971.

415. Silvani, Paul: Corse des années ardentes (1939-1976), Albatros, París, 1976.

416. SolÉ, M. Rosa: «L'estudi de la llengua i la qüestió nacional», Taula de Canvi, núm. 1, septiembre-octubre 1976, págs. 21-35.

417. Sosa WAGNER, Francisco: «Nuevas perspectivas en la ordenación regional francesa», Rivista Trimestrale di Diritto Pubblico, año 24, fasc. 3, 1973.

418. Verdaguer, Pere: «Al Rosselló, una conjuntura cultural i politica que s'encamina cap a una maduressa catalana», Nous Horitzons, núms. 47-48, octubre-noviembre 1978, págs. 113-121.

\subsection{Gran Bretaña}

419. Delion, A.: «Le régionalisme en Grande-Bretagne», Cabiers de l'Institut français des sciences administratives, núm. 1, 1967.

420. Grand, Jack, y MCCrone, Donald: «Le Parti national écossais: évolutions vers le nationalisme», Problèmes politiques et sociales, núm. 24, junio 1977.

421. Hanham, H. J.: Scottish Nationalism, Harvard University Press, Cambridge (Mass.), 1969.

422. HeFFer, Eric: «Le parti travalliste et la décentralisation», Problèmes politiques et sociaux, núm. 24, junio 1977.

423. Jones, G. W.: «Intergovernmental Relations in Britain», The Annals of the American Academy of Political and Social Science, vol. 416, noviembre 1974, págs. 181-193.

424. Kermode, D. G.: «Regional Self-Government: A Case. Study of the Isle of Man», Public Administration, núm. 52, 1974, págs. 161-178.

425. Mackintosh, J. P.: The Devolution of Power (Local Democracy, Regionalism, and Nationalism), Londres, 1968. 
426. Mackintosh, J. P.: «Le rapport de la Comission royale sur la Constitution», Problèmes politiques et sociaux, núm. 24, junio 1977.

427. Molinier, Jöel: «Les aspects financiers de la régionalisation dans le Royaume-Uni», en: GAUDEMET, Paul Marie (dir.): Les aspects financiers de la régionalisation en Europe, Notes et Etudes Documentaires, París, 1974, páginas $46-55$.

428. Morell, Juan: «Gran Bretaña: los problemas de la descentralización», Documentación Administrativa, núm. 176, octubre-diciembre 1976, páginas 111-158.

429. NAIRN, Tom: The break-up of Britain, New Left Books, Londres, 1977 (trad. italiana: Crisi e neonazionalismo. Il caso della Gran Bretagna, Liguori, Roma, 1979).

430. PILL, Roisin: «Social Implications of a Bilingual Policy, with Particular Reference to Wales», The Britisb Journal of Sociology, vol. 25 , núm. 1 , marzo 1974 , págs. 94-107.

431. Randali, P. J.: "Wales in the Structure of Central Government», Public Administration, núm. 50, 1972, págs. 353-370.

432. Rowlands, E. R.: «The Politics of Regional Administration: The Establishment of the Welsh Office», Public Administration, núm. 50, 1972, páginas 333-351.

433. SMITH, Brian C.: «Regional Administration and the Reform of Local Government in Britain», Rivista Trimestrale di Diritto Pubblico, año 23, número 1, 1972.

434. STEel, David: «Una position libérale: la solution féderale», Problèmes politiques et sociaux, núm. 24, junio 1977.

435. ThoRNHILL, William: The Case for Regional Reform, Londres, 1972.

\subsection{India}

436. BAUER, R.: «Die neugliederung der Indischen Union im Jahre 1956», Zeitschrift für ausländisches öffentliches und Völkerrechts, vol. 18, 1957.

437. Bombwall, K. R.: The Foundations of Indian Federalism, Asia Publishing House, Nueva York, 1967.

438. Gallagher, John; Johnson, Gordon, y Seal, Anil (eds.): Locality, province and nation: essays on Indian politics, 1870 to 1940, Cambridge University Press, Cambridge, 1973.

439. Hasan, Z.: "India in Kashmir», Pakistan Horizon, 1963, págs. 47-60.

440. Jones, P. H. M.: «India and the Nagas», Far Eastern Economic Review, septiembre 1962, págs. 389-396.

441. KodesIa, Krishna: The Problems of Linguistic States in India, Sterling Publishers, Delhi, 1969.

442. Krishna Moorthey, K., y Shams SiddiqI: «The Kashmir problem», Far Eastern Economic Review, 1962, págs. 344-355.

\subsection{Irak}

443. JABBAR, A.: «La question kurde en Irak», Nouvelle Revue Internationale, agosto, 1962 , págs. 53-64.

444. WENNER, L. M.: «Arab-Kurdish tivalties in Iraq», Middle Eastern Affairs, invierno-primavera 1963, págs. 68-82. 


\subsection{Irán}

445. CAmera D'AfflitTI, Isabella: «Il centralismo iraniano e le istanze di autonomie: il caso del Khuzistan», Política Internazionale, núm. 7, 1979.

446. Harrison, Selig S.: «Nightmare in Baluchistan», Foreign Policy, núm. 32, fall 1978, págs. 136-160.

447. KeDDIE, Nikki: «Religion and Irreligion in early Iranian Nationalism», Comparative Studies in Society and History, vol. 4, núm. 3, marzo 1962.

\subsection{Italia}

448. AlberICI, Aureliana: «Il ruolo delle autonomie locali nella riforma dell'Università», Il Mulino, núm. 250, 1977.

449. Albinati, Adriano: «Compresorio e Regione. Esperienze, problemi e prospettive», Arcbivio di Studio Urbanistica Regionale, núm. 2, 1977, páginas 129-154.

450. Amato, Giuliano: «Gli apparati centrali e le regioni», en: CASSESE, Sabino (ed.): L'amministrazione pubblica in Italia, Il Mulino, Bolonia, 1974, págs. 479-491.

451. Ambrosini, G.: L'ordinamento regionale, Zanichelli, Bolonia, 1957.

452. AnIASI, Aldo: I socialisti per gli enti locali, Edizioni delle Autonomie, Roma, 1979.

453. ArA, Angelo: «Spirito pubblico e politica italiana in Alto Adige dal plebiscito della Saar all'Anschluss. Premesse a una ricerca», Il Politico, año 40, núm. 1, 1975.

454. Argullol, Enrique: La vía italiana a la autonomia regional, Instituto de Estudios de Administración Local, Madrid, 1977.

455. Argullol, Enrique: «La práctica de la autonomía. Los primeros años de las regiones italianas», Revista de Administración Pública, núm. 87, septiembre-diciembre 1978, págs. 527-570.

456. BARBera, Augusto: Le istituzioni del pluralismo. Regioni e poteri locali: autonomie per governare, De Donato, Bari, 1977.

457. Barbera, Augusto, y BASSANINI, Franco: I nuovi poteri delle regioni e degli enti locali. Commentario al decreto 616 di attuazione della legge 382, I1 Mulino, Bolonia, 1978.

458. BARBIANI, L.: «La potestà legislativa delle Regioni a statuto ordinario in materia di polizia locale urbana e rurale», Amministrare, abril-junio 1975.

459. BARTOLE, Sergio: «Supremazia e collaborazione nei rapporti tra Stato e Regioni, Rivista Trimestrale di Diritto Pubblico, año 21, núm. 1, enero-marzo 1971.

460. Bassanini, Franco: «Aspetti costituzionali del trasferimento alle regioni delle funzioni amministrative in materia d'assistenza», Rivista Trimestrale di Diritto Pubblico, año 21, núm. 2, abril-junio 1971.

461. Bassanini, Franco: «Alcune reflessioni sui problemi attuali delle regioni a statuto speciale e sui rapporti tra autonomia regionale speciale e autonomia regionale ordinaria», Rivista Trimestrale di Diritto Pubblico, año 21, núm. 4, octubre-diciembre 1971.

462. Bassanini, Franco: L'attuazione delle Regioni, Florencia, 1970.

463. Bassanini, Franco: «L'autonomia statutaria delle Regioni al vaglio della Corte costituzionale», Giurisprudenza costituzionale, núm. 17, 1972.

464. Bassanini, Franco: Le Regioni fra Stato e comunità locali, Il Mulino, Bolonia, 1976. 
465. Bassanini, Franco: «L'expérience de la régionalisation en Italie», Revue Internationale des Sciences Administratives, vol. 43, núm. 1, 1977.

466. Benvenuti, Feliciano: «I controlli amministrativi dello Stato sulla Regione», Rivista Trimestrale di Diritto Pubblico, año 23, núm. 2, abril-junio 1972.

467. BerTI, Giorgio: «Autonomie locali intraregionali e esercizio delle funcioni amministrative regionali», Rivista Trimestrale di Diritto Pubblico, año 21, núm. 2, abril-junio 1971.

468. Biscaretti di Ruffia, Paolo: «Le Regioni in Italia nel 1954», Scritti per il centenario della Casa editrice Jovene, Nápoles, 1954.

469. Calandra, P., y Troccoli, G. (eds.): Il trasferimento delle funzioni statali alle Regioni, Roma, 1972.

470. Cammeli, Marco: «Indirizzo e coordinamento nel nuovo assetto dei rapporti fra Stato e regioni», Politica del Diritto, año 7, núm. 5, octubre 1976, páginas 573-618.

471. CARABbA, Manin: «Il mezzogiono: programmazione e regioni», Rivista Trimestrale di Diritto Pubblico, año 21, núm. 2, abril-junio 1971.

472. CARrassi, Alarico: «La Dc e la riforma regionale», Critica Marxista, año 11, núm. 5, septiembre-octubre 1973.

473. CASETTA, Elio: «La 'partecipazione democratica' nell'ordinamento regionale», Il foro amministrativo $e$ delle acque pubblicbe, núms. 8-9, agosto-septiembre 1972, págs. 875-881.

474. CASSESE, Sabino: «Le pianificazioni amministrative di settore e le regioni», Rivista Trimestrale di Diritto Pubblico, año 21, núm. 2, agosto-junio 1971.

475. Cavazza, Giampaolo: «Il diritto all'informazione negli Statuti regionali», Civitas, año 23, núm. 1, enero 1972.

476. Cavazza, Giampaolo: «La potestá legislativa delle Regioni», Civitas, año 23, núm. 9, septiembre 1972 .

477. Crofr, Paolo: «Analisi di una esperienza regionale: il Lazio», Critica Marxista, año 11, núm. 2, marzo-abril 1973.

478. Contt, Pietro; Cossutta, Armando; FantI, Guido; Modica, Enzo; Montemaggr, Loretta; Remondi, Cesare; Triva, Rubes, y Zangheri, Renato: Sviluppo della autonomie e riforma dello Stato, Editori Riuniti, Roma, 1975.

479. Cuocolo, Fausto: «Rapporti fra leggi statali e leggi regionali nelle materie di competenza ripartita», Rivista di Diritto Pubblico, núm. 1, enero-marzo 1970.

480. CHELI, Enzo: «Prospettive attuali nei rapporti tra regioni con speciale autonomia e regioni ordinarie», Rivista Trimestrale di Diritto Pubblico, año 21, núm. 2, abril-junio 1971.

481. DeugnIER, Raymond: «La régionalisation en Italie», Administration, número 69,1971 , págs. $83-88$.

482. Falzone, Guido: «I beni delle regioni a statuto ordinario», Rivista Trimestrale di Diritto Pubblico, año 21, núm. 2, abril-junio 1971.

483. Ferrando, Franco: «Le regioni nell'ordinamento amministrativo italiano», Nuova Rassagna di Legislazione, Dottrina e Giurisprudenza, núms. 3-4, 1972, págs. 187-196.

484. Ferrari, Pierre: Les régions italiennes, Presses Universitaires de France, París, 1972.

485. Ferrari, Pierre: «Les aspects financiers de la régionalisation en Italie», en GAUDEMET, Paul Marie (dir.): Les aspects financiers de la régionalisation en Europe, Notes et Etudes Documentaires, París, 1974, págs. 56-69.

486. Gallo, Nicola: "Crisi strutturale e questione meridionale», Critica Marxista, año 17, núm. 1, enero-febrero 1979, págs. 157-166.

487. Gasparri, G.: L'autonomia regionale sarda, Ed. S.E.I., Cagliari, 1952. 
488. Giannini, Massimo Severo: «L'esperienza regionale all'aprile 1971», Rivista Trimestrale di Diritto Pubblico, año 21, núm. 2, abril-junio 1971.

489. Groveno, L.: L'ordinamento regionale, Ministerio de l'Interno, Roma, 1960. 490. Gizzi, E.: Mannuale di Diritto regionale, Giuffré, Milán, 1972.

491. González Díaz-Llanos, Antonio E.: «Regiones autónomas y diversidad política en Italia, Boletín informativo de ciencia política, núm. 6, abril 1971, págs. 89-108.

492. Good, Martha H.: «Regional Reform and Subnational Autonomy: An Analitical Framework Applied to the Italian Case», Il Politico, año 42, número 1, 1977.

493. GRAMSCI, Antonio: La cuestión meridional, Dédalo, Madrid, 1978.

494. Instituto di Studi GiuRIDICI DELla Regione-Romagna: Le regioni per la riforma dello Stato. La legge 382 e l'attuazione dell'ordinamento regionale, Il Mulino, Bolonia, 1976.

495. JERI, Janko: «Les Slovènes en Italie», Questions actuelles du socialisme, vol. 24 , núm. 8,1974 , págs. $57-80$.

496. Legnani, Massimo (ed.): Regioni e Stato dalla Resistenza alla Costituzione, Il Mulino, Bolonia, 1975.

497. LEONI, Francesco: «Origen del nacionalismo italiano», Revista de Estudios Políticos, núm. 162, noviembre-diciembre 1968, págs. 141-148.

498. LuCIFREDI, Alberto: «Ciò che è urgente per le Regioni», Rivista Trimestrale di Scienza della Amministrazione, vol. 1, enero-marzo 1972, págs. 47-49.

499. Mazziottr, M.: Studi sulla potestà legislativa delle regioni, Milán, 1961.

500. Merloni, Francesco, y URBANI, Paolo: Il governo del territorio (tra Regioni e Partecipazione statali), De Donato, Bari, 1977.

501. Mrele, Giovanni: La Regione nella Costituzione italiana, Florencia, 1949.

502. Modica, Enzo: «Note sul problemi della lotta per le autonomie regionali e locali», Critica Marxista, año 6, número especial, 1968.

503. Modica, Enzo: Rapporti sulle regioni, Editori Riuniti, Roma, 1975.

504. Monaco, M.: Le Regione, sintesi storica dell'autonomia in Italia, Cinque Lune, Roma, 1957.

505. MoreTti, G. C.: La potestà finanziaria delle regioni, Giuffré, Milán, 1972.

506. MORATI, Costantino: «La regione nell'ordinamento costituzionale italiano», Studium, núm. 10, octubre 1947, págs. 331-340 (recogido en Raccolta di scritti, Giuffré, Milán, 1972, tomo I, págs. 521-541).

507. Mortati, Costantino: «Problemi dell'ordinamento regionale», Communità, núm. 13, 1952, págs. 14-17 (recogido en la Raccolta citada en la entrada precedente, tomo III, págs. 469-488).

508. Morati, Costantino: «Sulla potestà delle regioni ad emanre norme di diritto privato», Giurisprudenza Costituzionale, 1956, págs. 981-993 (recogido en la Raccolta, cit., tomo III, págs. 503-534).

509. Morati, Costantino: «I limiti della legge regionale», Raccolta, cit, tomo III, págs. 549-609.

510. ONIDA, Valerio: «Aspetti dell'autonomia della regione Valle d'Aosta», Rivista Trimestrale di Diritto Pubblico, año 21, núm. 2, abril-junio 1971.

511. Orazio, Giustino d': «Contributo allo studio delle funzioni costituzionali delle Regioni», Rivista Trimestrale di Diritto Pubblico, año 23, núm. 2, abril-junio 1972.

512. Paladin, L.: La potestà legislativa regionale, Cedam, Padova, 1958.

513. Paladin, L.: Manuale di diritto regionale, Giuffré, Milán, 1972.

514. Palazzoli, Claude: Les régions italiennes. Contribution à l'étude de la décentralisation politique, Librairie Génerale de droit et de jurisprudence, $\mathrm{Pa}$ rís, 1966. 
515. PIRAs, Aldo: «La burocrazia regionale», Sociologia, núm. 3, septiembre 1974, págs. 49-78.

516. RIzzo, G. B.: La Regione, Roma, 1947.

517. Romano, Alberto: «Rappresentenza politica e democrazia diretta nell'ordinamento regionale», Il foro amministrativo $e$ delle acque pubblicbe, números 8-9, agosto-septiembre 1972, págs. 882-889.

518. Ronchey, A.: Le autonomie regionali e la Costituzione, Fr. Bocca Ed., Milán, 1952.

519. Roversi-Monaco, Fabio: La delegazione amministrativa nel quadro dell'ordinamento regionale, Giuffré, Milán, 1970.

520. Roversi-Monaco, Fabio: «Potestà statutaria delle regioni», Sociologia, número 3, septiembre 1974, págs. 3-47.

521. Ruffilli, Roberto: La questione regionale dall'Unificazione alla Dittadura (1862-1942), Milán, 1971.

522. SANDUlit, Aldo M.: "I controlli sugli enti territoriali nella Costituzione», Rivista Trimestrale di Diritto Pubblico, año 23, núm. 2, abril-junio 1972.

523. Savignano, Aristide: «Democrazia participativa negli statuti regionali, Sociologia, núm. 3, septiembre 1974, págs. 119-148.

524. Schinaia, Mario E.: «L'attivitá delle regioni nei confronti degli enti locali», Rivista Trimestrale di Diritto Pubblico, año 25, núm. 4, 1975.

525. Serranr, Donatello: «Momento constituente e Statuti. Gli Statuti regionali fra innovazione e tradizione», Rivista Trimestrale di Diritto Pubblico, año 23, núm. 2, abril-junio 1972.

526. Siervo, U. de: Gli statuti delle Regioni, Milán, 1974.

527. Somogyr, Giovanni: «Aspectos económicos regionales y experiencias de política económica regional en Italia», Revista de Administración Pública, número 85 , enero-abril 1978, págs. 391-404.

528. Spaziante, Vicenzo: L'iniziativa legislativa delle regioni, Giuffré, Milán, 1978.

529. TERESI, Francesco: Il governo regionale. Aspetti funzionali, Giuffré, Milán, 1974.

530. TeresI, Francesco: «La legislazione d'intervento sui centri storici: aspetti evolutivi e competenze regionali», Rivista Trimestrale di Diritto Pubblico, año 25, núm. 4, 1975.

531. Tuccari, E.: Partecipazione popolare e ordinamento regionale, Giuffré, Milán, 1974.

532. VIGNOCCHI, Gustavo: «Attività amministrativa e di governo delle regioni. Appunti e riflessioni», Rivista Trimestrale di Diritto Pubblico, año 25, número 2, 1975.

533. VIRGA, Pietro: La Regione, Giuffré, Milán, 1949.

534. VIRGA; Pietro: La Regione a statuto speciale, Ed. Universitarie, Palermo, 1955.

535. Wooncok, George: «Aspects of the Italian Regional System», Il Politico, año 34, núm. 1, marzo 1969.

536. Woodcock, George: «Italy's New Regions», Il Politico, año 36, núm. 1, marzo 1971.

537. ZaCCARIA, Roberto: «Orientamenti recenti di giurisprudenza costituzionale in tema di regioni», Rivista Trimestrale di Diritto Pubblico, año 23 , número 4, 1973.

538. ZuCCARINI, O.: La Regione nell'ordinamento dello Stato: due concezioni, due soluzioni, Roma, 1945. 


\subsection{Malasia}

539. Gungwu, W.: «Malayan Nationalism», Royal Center Asian Journal, juliooctubre 1962, págs. 317-328.

540. Guyot, G. A.: «La naissance de la Malaisie et ses conséquences», Revue de Défense National, marzo 1964, págs. 448-462.

541. Roff, William R.: The Origins of Malay Nationalism, Yale University Press, New Haven (Mass.), 1968.

542. Starner, F. L.: «Malaysia and the Nort Borneo territories», Asian Survey, noviembre 1963, págs. 519-534.

543. Trlman, R. Q.: «Malaysia: the problems of federation», Western Political Quarterly, diciembre 1963, págs. 897-911.

\subsection{México}

544. Bataillon, Claude: «Décpupage administratif et régionalisation au Mexique. Problèmes d'Amerique Latine», Notes et Études Documentaires, núms. 3.884$3.885,1972$, págs. 79-86.

545. JIMÉNEZ RICARDEZ, Rubén: «El nacionalismo revolucionario en el movimiento obrero mexicano», Cuadernos Políticos, núm. 5, julio-septiembre 1975, págs. 47-64.

546. Lloyd Mechant, J.: «Mexican Federalism: Fact of Fiction?», Annals of the American Academy of Political and Social Sciences, núms. 108-113, 19411942.

547. Madrid Hurtado, M. de: «La división de poderes en las entidades de la federación mexicana», Revista de la Facultad de Derecho de México, octubre-diciembre 1963, págs. 869-892.

548. MoyA, Mario: «Federalismo y descentralización pública», Revue internationale des sciences administratives, vol. 40, núm. 1, 1974, págs. 15-22.

549. Prieto, E.: «Two Federal Republics: Mexico and the United States», American Bar Association Journal, vol. 41, núm. 10, octubre 1955, págs. 919-923.

550. SpaIN, A. O.: «Mexican Federalism Revisited», Western Political Quarterly, vol. 9 , núm. 3, septiembre 1956 , págs. 620.632 .

551. Turner, Frederick C.: The Dynamic of Mexican Nationalism, University of North Carolina Press, Chapel Hill (N. C.), 1968.

\subsection{Nigeria}

552. Akrwowo, Akinsola: «Tribalism and Nation-Building in Nigeria», Il Politico, año 37, núm. 1, marzo 1972.

553. Cola Alberich, Julio: «Secesión en la Federación de Nigeria», Revista de Política Internacional, núm. 92, julio-agosto 1967, págs. 149-162.

554. Cola Alberich, Julio: «Nuevos planteamientos del problema nigeriano», Revista de Política Internacional, núm. 97, mayo-junio 1968, págs. 213-223.

555. Mackintosh, J. P.: «Federalism in Nigeria», Political Studies, octubre 1962, págs. 223-247.

556. MARIÑAs OTERo, Luis: «Nigeria, raíces de una crisis», Revista de Política Internacional, núm. 99, septiembre-octubre 1968, págs. 107-134.

557. Mữoz, Luis Joaquín: «La República de Nigeria, una situación federal», Revista de Estudios Políticos, núms. 165-166, mayo-agosto 1969, páginas 83-117. 


\subsection{Suiza}

558. Barrena, Alberto María: El federalismo en Suiza, Instituto de Estudios Políticos, Madrid, 1970, 2 vols.

559. BASSAND, Michel: «Le séparatisme jurassien: un conflict de classes et/ou conflit ethnique?», Cabiers Internationaux de Sociologie, vol. 61, 1976, páginas 221-246.

560. DORMANN, A.: Interkantonale Institutionen mit Hobeitsbefugnissen, Schulthess, Zurich, 1970.

561. Giacometti, Z., y Fleiner, F.: Schweizerisches Bundesstaatsrecht, Poligraphischer Verlag A. G., Zurich, 1949.

562. Gueli, V.: La Costituzione federale Svizzera, Sansoni, Florencia, 1946.

563. Hughes, Christopher: The Federal Constituion of Switzerland, Oxford, 1954.

564. PrIvat, Edmond: Trois experiénces féderalistes, La Bacconière, Neuchâtel, 1942.

565. Rappard, William E.: La Constitution fédérale de la Suisse, La Bacconière, Neuchâtel, 1948.

566. RufFieux, Roland: «L'Administration cantonale: tentative de réforme en Suisse romande», Revista del Instituto de Ciencias Sociales, núm. 18, 1971.

567. Schindler, D.: «Die Entwicklung des Föderalismus in der Schweiz», Jabrbucb des öffentlichen Recbts der Gegenwart, vol. 9, 1960.

568. Thurer, Daniel: Das Selbstbestimmungsrecht der Völker, Mit einen Exkurs zur Jurafrage, Stämpfli, Berna, 1976.

\subsection{Unión Soviética}

569. AlLWORTH, Edward (ed.): Soviet Nationality Problems, Columbia University Press, Nueva York, 1971.

570. Becker, Seymour: Russia's Protectorates in Central Asia: Bukbara and Kbiva, 1865-1924, Harvard University Press, Cambridge (Mass.), 1968.

571. Benningsen, A., y QuelquejAy, C.: Les mouvements nationaux chez les musulmans de Roussie: le sultangalievisme de Tatarstan, Mouton, París, 1950.

572. BEYME, Klaus von: Der Föderalismus in der Sowjetunion, Heidelberg, 1964.

573. BELR, H. G.: «Das Prinzip des Föderalismus in der Sowjetunion», Jabrbuch des öffentlicben Rechts der Gegenwart, vol. 12, 1962.

574. Carrere D'ENCAusse, Hélène: «Note sur: Bolchevisme et nation, des débats théoriques à la consolidation d'un Etat multinational 1917-1929, de Georges Mondo», Est-Ouest, vol. 8, núm. 1, enero-marzo 1977.

575. Carrere D'Encausse, Hélène: «Party and Federation in the USSR», Government and Opposition, vol. 13, núm. 2, primavera 1977, págs. 133-150.

576. Carrere d'EnCausse, Hélène: L'Empire eclaté, Flammarion, París, 1978.

577. ChJIKvadze, Viktor: «Significado histórico de la formación del Estado federal soviético», Ciencias Sociales, núm. 10, 1972, págs. 36-50.

578. Goldhagen, Enrich (ed.): Etbnic Minorities in the Sovit Union, Praeger, Nueva York, 1968.

579. Ladreit DE LA Charriere, G.: L'idée féderale en Russie de Riourik à Staline, Pedone, París, 1945.

580. LANG, David M.: «Religion and Nationalism. A Case Study: The Caucasus», Survey, núm. 66, 1968, págs. 33-47.

581. Lavigne, Pierre: «Etat unitaire et Etat féderal», Annales de la Faculté de Droit et des Sciences Politiques et Economiques de Strasbourg, tomo 20, 1966, págs. 185-224. 
582. MouskHely, Michael: «Les contradictions du féderalisme soviétique», en el volumen colectivo L'URSS Droit, Economie, Sociologie, Politique, Culture, Sirey, París, tomo I, págs. 19-33.

583. MunLeN, Patrick von zur: «Hapan und die sowjetische Nationalitätenfrage am Vorabend und während des Zweiten Weltkrieges», Vierteljabrsbefte für Zeitgeschicbte, tomo 21, núm. 3, 1973, págs. 325-333.

584. PIPES, Richard: The Formation of the Soviet Union: Communism and Nationalism, 1917-1923, Harvard University Press, Cambridge (Mass.), 1954.

585. RogGer, Hans: «Nationalism and the State: a Russian Dilemma», Comparative Studies in Society and History, vol. 4, núm. 3, marzo 1962.

586. SILVER, Brian D.: «The Status of National Minority Languages in Soviet Education: An Assesment of Recent Changes», Soviet Studies, vol. 26, número 1, 1974, págs. 28-40.

587. SILVER, Brian: «Social Mobilization and the Russification of Soviet Nationalities», The American Political Science Review, vol. 68, núm. 1, marzo 1974, págs. 45-66.

588. SIlver, Brian: «Levels of Sociocultural Development Among Soviet Nationalities: A Partial Test of the Equalization Hypothesis», The American Political Science Review, vol. 68, núm. 4, diciembre 1974, págs. 1618-1637.

589. Simon, Gerhard: «Sowjetische Nationalitätenpolitik», Politische Studien, número 214, 1974, págs. 167-173.

590. SOROZÁbAL, Juan José: «Sobre la política de las nacionalidades en la Unión Soviética», Saioak, núm. 2, 1978, págs. 231-239.

591. Tadevosian, Eduard: «La unidad de lo internacional y lo nacional en el sistema estatal de los pueblos de la URSS», Ciencias Sociales, vol. 18, núm. 6, 1974, págs. 135-147.

\subsection{Venezuela}

592. Agudo FrEITES, Raúl: «Esquema del régimen federal en Venezuela», Revista del Colegio de Abogados del Distrito Federal, núms. 99-100, julio-octubre 1956.

593. Aguado Fretres, Raúl: Esquema del régimen federal en Venezuela, Imp. El Cojo C. A., Caracas, 1957.

594. BRITo GonzÁlez, José: «Bases reales de la Constitución de 1811 y pervivencias federales ante tendencias centralistas posteriores», Politeia, núm. 5 , 1976, págs. 253-272.

595. Dana Montaño, Salvador M.: «Sobre el federalismo», Revista de la Facultad de Derecho, núm. 5, mayo-agosto 1962.

596. IZQUIERDA CORSER, N.: «Aspectos administrativos de la regionalización en Venezuela», Revue Internationale des Sciences Administratives, vol. 38, número 3, 1972, págs. 319-326.

597. SÁNCHEZ, Jesús Leopoldo: «Federalismo y centralismo. Bases para una nueva división territorial venezolana», Gaceta Universitaria, núm. 17, junio 1946.

\subsection{Yugoslavia}

598. Colakovic, Rodoljub: «La Bosnie-Herzégovine et le réglament de la question nationale», Questions actuelles du socialisme, año 24, núm. 3, 1974, páginas 3-16.

599. Dogo, Marco: «La Lcj e la questione nazionale», Critica Marxista, año 11, núm. 5, septiembre-octubre 1973. 
600. FIsHer, Jack C.: Yugoslavia-A Multinational State, Chandler, San FrancisCo, 1966.

601. GRULICH, Rudolp: «Die kulturalle Situation der nationalen Minderheiten un Jugoslawien», Politischen Studien, núm. 212, 1973, págs. 621-629.

602. Hondius, Frits W.: The Yugoslav Community of Nations, Mouton, La Haya, 1968.

603. Jambrex, Peter: Development and Social Change in Yugoslavia: Crises and Perspectives of Building a Nation, Lexington Books, Lexington (Mass.), 1975.

604. Jelicic, Milivoje: «Les fonctions économiques des républiques dans la Féderation yougoslave», Questions actuelles du socialisme, año 24, núm. 1, 1974, págs. 35-56.

605. Joncic, Koča: Relaciones entre las naciones y las minorías nacionales de Yugoslavia, Medunarodna Politika, Belgrado, 1969.

606. KaTZ, Daniel; Delamater, John, y Stojic, Ljuba: «Nacionalismo en el Estado multinacional de Yugoslavia», Revista de Estudios Sociales, núms. 10-11, enero-agosto 1974, págs. 11-39; núms. 14-15, mayo-diciembre 1974, páginas $11-50$.

607. LAH, Avguštin: La Federación yugoslava: ¿qué es? Posición de las naciones $y$ nacionalidades en la Federación autogestionaria, Medunarodna Politika, Belgrado, 1973.

608. Meneghello-Dincic, K.: Le nouveau fédéralisme yougoslave, Notes et Etudes Documentaires, Paris, 1972.

609. ScHultz, Lothar: «Die Verfassungsentwicklung der Föderativen Yugoslawien seit 1945», Jabrbuch der öffentlichen Rechts der Gegenwart, vol. 7, 1958.

610. SCHultz, Lothar: «Autonomie und Föderalismus in der Verfassung Jugoslawiens», Donauraum, vol. 13, núm. 3, 1968, págs. 171-178.

611. SHoup, Paul: Communism and the Yugoslav National Question, Columbia University Press, Nueva York, 1968.

612. Stroвl, Majda: «Les compétences de la Fédération selon la Constitution yougoslave de 1974», Yugoslav Law. Droit Yougoslave, núm. 2, 1975, páginas 3-12.

613. Suvar, Stipe: «Nazione e socialismo en Jugoslavia», Critica Marxista, año 11, núm. 5, septiembre-octubre 1973.

614. Trтo, Josip Broz: «La question nationale en Yugoslavie à la lumière de la lutte de libération», Questions actuelles du socialisme, año 24, núm. 10, 1974 , págs. 38-47.

615. VLAHOVIC, Veljko: «Thèses sur la question nationale macédonienne», Questions actuelles $d u$ socialisme, año 25 , núm. 5, 1975, págs. 50-64.

\section{FEDERALISMO, NACIONALISMO Y REgIONALISMO EN ESPAÑA}

\subsection{Obras clásicas (anteriores a 1931)}

616. BraÑas, Alfredo: El regionalismo. Estudio sociológico, histórico y literario, Barcelona, 1889.

617. BRAÑAS, Alfredo: La crisis económica en la época presente y la descentralización regional, Imprenta de José M. Paredes, Santiago de Compostela, 1892.

618. García Ácuña, José: Ideárium regionalista. Esquema sintético de la evolución regional ibérica, La Coruña, 1925.

619. GARRIDO, Fernando: La República democrática federal universal, Imprenta de Juan Iniesta, Madrid, $1881,16 .^{2} \mathrm{ed}$. 
620. MAÑE y FlaQUeR, Juan: El regionalismo, Imprenta Barcelonesa, Barcelona, 1887.

621. Pi y Margall, Francisco: Las nacionalidades, Edicusa, Madrid, 1968.

\subsection{Monografías bistóricas contemporáneas}

622. Alfonso Bozzo, Alfonso: Intelectuais e galeguismo (Ensaio encol da bistoria do pensamento nacionalista galego), Akal, Madrid, 1977.

623. Alfonso Bozzo, Alfonso: «Entorns del pensament del galleguisme: els origens, Risco i Castelao», Recerques, núm. 8, 1978, págs. 133-158.

624. Alvarez, Santiago: «Origen y formación de la nacionalidad gallega», Nuestras Ideas, núm. 12, julio 1961.

625. Alvarez, Santiago: Las nacionalidades en España. Antecedentes bistóricos, Forma, Madrid, 1978.

626. Arnau, Roger: Marxisme catalá $i$ qüestió nacional catalana, 1930-1936, Edicions Catalanes de Paris, París, 1974.

627. Beltza: El nacionalismo vasco, 1876-1936, Txertoa, San Sebastián, 1976.

628. Carretero y Jiménez, Anselmo: La integración nacional de las Españas, México, 1957.

629. Carretero y Jiménez, Anselmo: «En torno a las autonomías», Historia Libertaria, núm. 2, enero 1979, págs. 41-51.

630. Centro DE Estudios MonTAÑEses: Antecedentes bistóricos y culturales de la provincia de Santander como región, Institución Cultural de Cantabria, Santander, 1978.

631. Corcuera, Javier: «Tradicionalismo y burguesía en la formulación del nacionalismo vasco. Lucha de clases y lucha nacional en Euskadi», Materiales, núm. 5, septiembre-octubre 1977, págs. 103-114.

632. Cores Trasmonte, Baldomero: «A. Faraldo y el regionalismo gallego», Boletín informativo de ciencia política, núm. 10, agosto 1972, págs. 91-111.

633. Cores Trasmonte, Baldomero: «'Bases Generales del Regionalismo y su aplicación a Galicia' (1892), de Alfredo Brañas», Revista de Estudios Políticos, núm. 206-207, marzo-junio 1976, págs. 203-245.

634. Cuco, Alfons: El valencianisme politic, 1874-1936, Garbi, Valencia, 1971.

635. Cuco, Alfons: Valencianismo y estatuismo, Fernando Torres, Valencia, 1976.

636. ElorzA, Antonio: Ideologías del nacionalismo vasco, Luis Haramburu, San Sebastián, 1978.

637. ERDERA, Mikel: «Conciencia nacional y conciencia de clases (Notas para un análisis marxista de las nacionalidades hispanas)», Realidad, núm. 22, enero 1972, págs. 1-11.

638. Escudero, Manu, y Villanueva, Javier: La autonomía del País Vasco desde el pasado al futuro, Txertoa, San Sebastián, 1977.

639. Fernández Clemente, Eloy, y Forcadell, Carlos: «Las raíces del autonomismo aragonés», en Id.: Estudios de Historia Contemporánea de Aragón, Facultad de Ciencias Económicas y Empresariales, Zaragoza, 1978, páginas 143-154.

640. Fontana, Josep: «Reflexions sobre la unitat histórica dels Països Catalans», Taula de Canvi, núm. 3, enero-febrero 1977, págs. 5-11.

641. García FERnÁndez, Javier: «El nacionalismo vasco como problema metodológico», Documentación Social, núm. 16, octubre-diciembre 1974, págs. 49-60.

642. García Venero, Maximiano: Historia del nacionalismo catalán, Ed. Nacional, Madrid, 1967, 2.. ed.

643. García Venero, Maximiano: Historia del nacionalismo vasco, Ed. Nacional, Madrid, $1969,3 .^{\mathrm{a}}$ ed. 
644. González Casanova, Josep Antoni: Federalisme $i$ autonomia a Catalunya, 1868-1938, Curial, Barcelona, 1974.

645. Heiberg, Marianne, y Escudero, Manu: «Sabino de Arana: la lógica del nacionalismo vasco», Materiales, núm. 5, septiembre-octubre 1977, páginas 87-101.

646. LACOMBA, Juan Antonio: «En torno al regionalismo andaluz», Jábaga, número 10 , junio 1975 , págs. 49-52.

647. LacombA, Juan Antonio: «Andalucía: trayectoria de un regionalismo», Gibralfaro, núm. 27, 1975, págs. 153-167.

648. LluL, Anselm: El mallorquinisme polític (1840-1936), Edicions Catalanes de Paris, París, 1975.

649. Mainer, José Carlos: «El aragonesismo político (1868-1936)», Sistema, número 8, enero 1975, págs. 57-71.

650. MenÉNDeZ-VÁldez Golpe, Eduardo: Separatismo y unidad (una mitificación bistórica), Seminarios y Ediciones, Madrid, 1973.

651. Olcina, Evarist: El carlismo y las autonomias regionales, Seminarios y Ediciones, Madrid, 1974.

652. ORTzI: Historia de Euskadi. El nacionalismo vasco y la ETA, Ruedo Ibérico, París, 1975.

653. Payne, Stanley G.: «Catalan and Basque Nationalism», Journal of Contemporary History, vol. 6, 1971, págs. 15-51.

654. Payne, Stanley G.: El nacionalismo vasco, Dopesa, Barcelona, 1976.

655. PoBlet, Josep María: História básica del nacionalisme, Pórtic, Barcelona, 1975.

656. Ramos OlrveIra, Antonio: La unidad nacional y los nacionalismos españoles, Grijalbo, México, 1969.

657. Rovira I VIRGILI, Antoni: «EI problema de las nacionalidades hispanas», Cuadernos del Congreso por la libertad de la cultura, núm. 2, junio-agosto 1953, págs. 42-47.

658. Royo Villanova, Carlos: El regionalismo aragonés (1707-1978). La lucba de un pueblo por su autonomia, Guarda, Zaragoza, 1978.

659. Santamaría Pastor, Juan Alfonso; Orduña Rebollo, Enrique, y MartínArtajo, Rafael: Documentos para la bistoria del regionalismo en España, Instituto de Estudios de Administración Local, Madrid, 1977.

660. Solé-Tura, Jordi: Catalanismo y revolución burguesa, Edicusa, Madrid, 1970.

661. SolozÁbal, Juan José: El primer nacionalismo vasco. Industrialización y conciencia nacional, Túcar, Madrid, 1975.

662. Termes, Josep: «Interpretación del nacionalismo catalán», Cuadernos de Ruedo Ibérico, núms. 49-50, enero-abril 1976, págs. 41-53.

663. Torrent, Rafael: Dos federalismos y su pugna en España desde los orígenes de la Primera República, Dopesa, Barcelona, 1974.

664. Trías Vejarano, Juan J.: «El nacionalismo catalán en su perspectiva histórica», Razón y Fe, núm. 916, mayo 1974, págs. 409-426.

665. Trujillo, Gumersindo: Introducción al federalismo español, Edicusa, Madrid, 1967.

\subsection{El problema nacional en la Segunda República}

666. Els Estatuts del País Valencid, La Magrana, Barcelona, 1977.

667. Academia de Jurisprudencia I Legrslació de Catalunya: Confèrencies sobre l'Estatut de Catalunya, Casacuberta, Barcelona, 1933. 
668. Alfonso Bozzo, Alfonso: Los partidos políticos y la autonomía de Galicia, Akal, Madrid, 1976.

669. Ambrosini, Gaspare: «Un tipo intermedio di Stato tra l'unitario e il federale caratterizato dall'autonomia regionale», Rivista di Diritto Pubblico, 1933, págs. 92-100.

670. Arias Velasco, J.: La Hacienda de la Generalitat, 1931-1938, Ariel, Barcelona, 1977.

671. ARnAU, Roger: Marxisme català i qüestió nacional, 1930-1936, Edicions Catalanes de Paris, París, 1974.

672. Astarloa, Francisco: Región y religión en las Constituyentes de 1931, Cátedra Fadrique Furió Ceriol, Valencia, 1976.

673. BALCELLS, Albert: «E1 Estatuto Catalán en su marco histórico. La Generalitat, concesión de un Estado centralista», Historia Internacional, núm. 13, abril 1976, págs. 13-23.

674. BarraIL, Henri: L'autonomie régionale en Espagne, Librairie Générale de Droit et de Jurisprudence, París, 1933.

675. BENET, Josep: «Gabriel Alomar i l'Autonomia», Nous Horitzons, núms. 4748, octubre-noviembre 1978, págs. 33-44.

676. Bonamusa, Francesc: «L'Administració de Justícia á Catalunya (setembre-desembre 1936)», Recerques, núm. 4, 1974, págs. 191-222.

677. Bosch-Gimpera, Pere: «La Conselleria de Justícia de la Generalitat. De 1937 a la fi de la guerra», Xaloc, núm. 52, 1972, págs. 103-106; núm. 53, 1972, págs. 131-134; núm. 55, 1972, págs. 166-170.

678. Bricall, Josep M., y OArellada, Martí: «El finançament de l'autonomia catalana durant la guerra», L'Avenç, núm. 20, octubre 1979, págs. 25-31.

679. Broggi, Josep María, y OBIols, Margarida: «Articulació de compètencies entre la Segona República i la Generalitat. El succesiu traspàs de serveis», Revista Jurídica de Catalunya, año 76, núm. 3, julio-septiembre 1977.

680. Camps I Arborx, Joaquim: El Parlament de Catalunya (1932-1936), Edicions 62, Barcelona, 1976.

681. Castelao, Alfonso R.: O Estatuto de Galiza. Antecedentes e comentarios, Ed. Nos, Buenos Aires, 1975.

682. Castells, José Manuel: El Estatuto vasco. El Estado regional y el proceso estatutario vasco, Luis Haramburu, San Sebastián, 1976.

683. CASTElls, José Manuel: «La aplicación autonómica del Gobierno vasco», Revista de Administración Pública, núm. 84, septiembre-diciembre 1977, páginas 121-144.

684. Closas, R.: El problema del régim transitori de Catalunya, Biblioteca Jurídica de Catalunya, Barcelona, 1935.

685. Cuco, Alfons: «L'anarcosindicalisme i l'Estatut d'autonomia del País Valencià (1936-1939)», Recerques, núm. 2, 1972, págs. 209-222.

686. Cuco, Alfons: «La problemática de l'Estatut Valencià durant la guerra civil: l'Avant-projecte d'Esquerra Valenciana (1937)», Primer Congreso de Historia del País Valenciano, Valencia, 1974, vol. IV, págs. 727-740.

687. Cucurull, Félix: La defensa de l'Estatut d'autonomia de Catalunya, Undarius, Barcelona, 1976.

688. Dot, Antonio: «El Parlamento Catalán durante la República», Libro Blanco de Cataluña, Eds. de la Revista Catalunya, Buenos Aires, 1956, págs. 81-84.

689. Elorrieta y Artaza, Felipe: La Constitución, los proyectos de Estatuto vasco y el régimen de conciertos económicos, Escuelas Gráficas de la Santa Casa de Misericordia, Bilbao, 1932.

690. Fernández Clemente, Eloy, y Forcadell, Carlos: «El Estatuto de Caspe», 
en Id.: Estudios de Historia Contemporánea de Aragón, Facultad de Ciencias Económicas y Empresariales, Zaragoza, 1978, págs. 168-192.

691. García Alvarez, Manuel B.: «La voluntad regional como otigen de autonomía política en la II República», Sistema, núm. 14, julio 1976, páginas 73-93.

692. García Alvarez, Manuel B.: «La cuestión lingüística en las Cortes Constituyentes de la II República», Revista de Derecbo Público, núm. 71, abriljunio 1978, págs. 307-318.

693. GAYA PICón, José: La autonomía de las regiones (antecedentes, opiniones $y$ orientaciones para la solución del problema), Castro, Madrid, 1932.

694. GERPE, Manuel: L'Estatut d'autonomia de Catalunya i l'Estat integral, Edicions 62, Barcelona, 1976.

695. GERPE, Manuel: «El règim polític de la Generalitat de Catalunya (19311936)», Taula de Canvi, núm. 11, mayo-agosto 1978, págs. 5-14.

696. Gonź́lez Casanova, José Antonio: «La Constitución de la Segunda República española y el 'Estatut de Catalunya' de 1931», Sistema, núms. 17-18, abril 1977, págs. 99-110.

697. Hernández Lafuente, Adolfo: «Los referéndums de autonomía en la II República», Revista de Estudios Políticos, núm. 5, 2. ápoca, septiembre-octubre 1978, págs. 97-119.

698. Huguet, Josep M., y Vilalta, Jaume: «Les finances de la Generalitat (1931-1936)», L'Avenç, núm. 20, octubre 1979, págs. 19-24.

699. JIMÉNEZ DE AsúA, Luis: La Constitución de la democracia española y el problema regional, Losada, Buenos Aires, 1946.

700. Larraz, José: La Hacienda Pública y el Estatuto Catalán, Ed. Ibérica, Madrid, 1932.

701. LESAFRe, J.: Le problème national de la Catalogne et sa solution par le Statut de 1932, Imp. Mari-Lavil, Montpellier, 1934.

702. LloRÉNS, Eduardo: La autonomía en la integración política. El Estatuto de Cataluña, Ed. Revista de Derecho Privado, Madrid, 1932.

703. Martín-Retortillo, Lorenzo: «La experiencia de los Estatutos de Autonomía en la Segunda República española», en SEminario de Estudios AragoNESES: Caspe: un Estatuto de autonomía para Aragón, Alcrudo, Zaragoza, 1977, págs. 7-22.

704. Maspons I Anglasell, F.: La Generalitat de Catalunya i la República Espanyola, Occitània, Barcelona, 1932.

705. Masso I Escofet, C.: «La Hacienda de Cataluña según el Estatuto del 15 de septiembre de 1932», Revista Nacional de Economía, núms. 104-105, 1932.

706. Molas, Isidre: «EI Govern d'Ignasi Villalonga de la Generalitat de Catalunya (25 de novembre-14 de desembre de 1935)», Arguments, núm. 1, 1974, págs. 131-155.

707. Molas, Isidre: «Els institucions polítiques del Pais Valencià segon l'avantproject d'Estatut d'Autonomia d'onze de juliol de 1931», Primer Congreso de Historia del País Valenciano, Valencia, 1975, vol. IV, págs. 691-700.

708. OBIols, Margarida: «EI traspàs de compètencies de la Segona República a la Generalitat», Taula de Canvi, núm. 11, mayo-agosto 1978, págs. 15-29.

709. Orueta, José: Fueros y autonomía. Proceso del Estatuto Vasco, Imprenta Nueva Editorial, San Sebastián, 1934.

710. PÉREZ Noragó, Francesc: «Un Estatuto nonnato. Las primeras redacciones de un "Estatut del País Valencià'», Historia Internacional, núm. 12, marzo 1976, págs. 30-33. 
711. PÉrez Serrano, Nicolás: «La 'Organización nacional' en la vigente Constitución», Administración y Progreso, núm. 7, 15 noviembre 1932, págs. 4-6.

712. Pi Sunyer, Carles: «Los Gobiernos de la Cataluña autónoma», Libro Blanco de Cataluña, Eds, de la Revista de Catalunya, Buenos Aires, 1956, páginas 85-94.

713. Pr SunYer, Carles: La Generalitat de Catalunya. Els Governs de la Catalunya Autónoma, Terra Ferme, Caracas, 1973.

714. Pitarch, Ismael E.: «La Diputació Provisional de la Generalitat», Revista Jurídica de Cataluña, año 75, núm. 4, octubre-diciembre 1976.

715. Pitarch, Ismael E.: La Generalitat de Catalunya. Els Governs, Undarius, Barcelona, 1976.

716. Pitarch, Ismael E.: L'estructura del Parlement de Catalunya i les seves foncions polítiques (1932-1939), Curial, Barcelona, 1977.

717. Pitarch, Ismael E.: «El Parlamento de Cataluña en la segunda Generalidad (1932-1939)», Revista de Estudios Políticos, núm. 3, 2. á época, mayojunio 1978 , págs. $55-77$.

718. Ribas I MASSana, Albert: «Constitució, Estatut d'Autonomia i Universitat als anys trenta», Taula de Canvi, núm. 10, marzo-abril 1978, págs. 48-56.

719. Rıb6, Rafael: «La alternativa catalana: el Estatuto de 1932 como punto de partida», Zona Abierta, núm. 13, 1977, págs. 34-40.

720. Roig I BergadA, J.: «De la función judicial en el Estatuto catalán», Revista Nacional de Economia, núms. 104-105, 1932.

721. Rovira I VIrGILI, Antoni: «La Generalitat i el Govern espanyol», Revista de Catalunya, núm. 80, 1934.

722. Royo Villanova, Segismundo: «El Estado integral», Revista de Derecbo Público, núm. 45, septiembre 1935, págs. 261-273.

723. SAGUES, Miguel: «El euskera y la enseñanza en los estatutos de autonomía», Saioak, núm. 1, 1977, págs. 49-66.

724. SAINz VALdivieso, Alfonso C.: «Religión y política en el Estatuto Vasconavarro. 1936: Autonomía para la oligarquía», Historia Internacional, núm. 12, marzo 1976, págs. 24-29.

725. SAINZ DE VARANDA, Ramón: «La autonomía de Aragón en el período del Frente Popular», en el vol. colectivo: VIII Coloquio de Pau: La crisis del Estado español, 1898-1936, Edicusa, Madrid, 1978, págs. 517-533.

726. SARrIÁ, Joan de: L'expériencia de l'Estatut d'autonomia de 1932, Club del Llibre Catalá, México, 1972.

727. Sentís Melendo, Santiago: «La Justicia en Cataluña durante la República y la guerra», Libro Blanco de Cataluña, Eds. de la Revista Catalunya, Buenos Aires, 1956, págs. 105-109.

728. Simó, Guillem: «Notes per a una história del projecte d'Estatut d'Autonomia de les Illes de 1931", Randa, núm. 3, 1976, págs. 5-70.

729. Sobrequés I CAllic6, Jaume: Catalunya i l'Estatut d'autonomia, Undarius, Barcelona, 1976.

730. Sobrequés I Callico, Jaume: El Estatuto de autonomía de Cataluña, Undarius, Barcelona, 1977.

731. Tarradellas, Josep, y Sobrequés, Jaume: Qué es la Generalitat de Catalunya, La Gaya Ciencia, Barcelona, 1977.

732. Valis I TABERNER, Ferrán: «Precedents i fonts de l'Estatut de Catalunya», Revista Jurídica de Catalunya, año 38, núm. 4, octubre-diciembre 1932, páginas 293-304.

733. Varela, Santiago: El problema regional en la segunda República, Unión Editorial, Madrid, 1976. 
734. Vilas Nogueira, José: O Estatuto Galego, Eds. do Rueiro, La Coruña, 1975.

735. VILASECA I MARCET, Josep M.: «Descentralització i Finances Publiques», Revista Jurídica de Cataluña, año 74, núm. 2, 1975.

736. VilaseCA I MARCET, Josep M.: «Les finances de la Generalitat», Taula de Canvi, núm. 11, mayo-agosto 1978, págs. 23-29.

\subsection{El problema nacional y regional antes de la Constitución de 1978}

737. Acosta, José: Andalucia. Reconstrucción de una identidad y la lucha contra el centralismo, Anagrama, Barcelona, 1978.

738. Alburquerque, Francisco: «La cuestión nacional y el subdesarrollo en Andalucía», Negaciones, núm. 3, mayo 1977, págs. 161-172.

739. Alvarez, Santiago: «Notas sobre el problema nacional en España», Nuestra Bandera, núm. 84, marzo-abril 1976, págs. 13-25.

740. Alvarez-Gendín, Sabino: «Las regiones», Rivista Trimestrale di Diritto Pubblico, año 25 , núm. 2, 1973, págs. $710-732$.

741. ARANZADI, Juan: «Milenarismo vasco y antisemitismo democrático», El Viejo Topo, núm. 30, marzo 1979, págs. 15-21.

742. ARdiaCA, Pete: «Perspectives d'una solució democràtica al problema nacional català», Horitzons, núm. 1, cuarto trimestre 1960, págs. 4-12.

743. Arenillas, José María: Euzkadi, la cuestión nacional y la revolución socialista, París, 1969.

744. Arias Veira, Pedro: «La problemática nacional gallega», Materiales, núm. 2, marzo-abril 1977, págs. 15-38.

745. Arias Veira, Pedro, y Maíz, Ramón: «La cuestión nacional en Galicia: notas para un enfoque», Zona Abierta, núm. 11, 1977, págs. 57-80.

746. BarCEL6, Miquel: «Una nota sobre la cuestión nacional 'española'», en el volumen colectivo Comunistas y/o nacionalistas, Anagrama, Barcelona, 1977, págs. 155-166.

747. BASTIDA FreIJIDo, Francisco J.: «La unidad nacional como principio ideológico del pensamiento político del Tribunal Supremo español», Sociología y Psicología Jurídicas, núm. 4, 1977, págs. 65-81.

748. BELTZA (Emilio LóPEZ ADÁN): Nacionalismo vasco y clases sociales, Txertoa, San Sebastián, 1976.

749. Bergasa, Oscar: «Canarias, región marginal», Argumentos, núm. 19, enero 1979 , págs. $40-44$.

750. Cambre Mariño, Xesús: Galicia de boxe: problematica dun pobo en crise, Edicions Galicia, Buenos Aires, 1973.

751. Cambre Mariño, Xesús: «El fenómeno del regionalismo: una visión gallega del problema», Sistema, núm. 13, abril 1976, págs. 77-98.

752. Campo, Salustiano del; Navarro, Manuel, y Tezanos, José Félix: «Los españoles ante la cuestión regional», Sistema, núm. 13, abril 1976, págs. 99-127.

753. Campo, Salustiano del; Navarro, Manuel, y Tezanos, José Félix: La cuestión regional española, Edicusa, Madrid, 1977.

754. Castelao, Alfonso R.: «La posición ideológica de Galicia», Galeuzca, número 1 , agosto 1945 .

755. Comorera, Joan: El problema de les nacionalitats a Espanya, Publicaciones Catalunya, México, 1942.

756. CORES TRASMONTE, Baldomero: «Sociología regional: la cultura gallega y la sociedad de masas», Revista de Letras, núm. 6, junio 1970, págs. 151-187. 
las regiones autónomas», Estudios sobre el proyecto de Constitución, Centro de Estudios Constitucionales, Madrid, 1978, págs. 685-702.

825. Corcuera, Javier: «Notas en torno al tema de los derechos históricos», Argumentos, núm. 17, noviembre 1978, págs. 61-63.

826. Cosculluela, Luis: «En torno a las transferencias de funciones a las Comunidades Autónomas», Civitas. Revista Española de Derecho Administrativo, núm. 18, julio-septiembre 1978, págs. 367-380.

827. EMbID Irujo, Antonio: «Algunas reflexiones sobre el hecho regional: la ideología del sistema, los problemas de la competencia y la polémica sobre la generalización de la potestad legislativa regional», en RAMírEz, Manuel (ed.): Estudios sobre la Constitución española de 1978, Pórtico, Zaragoza, 1979, págs. 307-319.

828. Fernández, Tomás Ramón: «La organización regional. Apunte crítico del Anteproyecto de Constitución», Estudios sobre el proyecto de Constitución, Centro de Estudios Constitucionales, Madrid, 1978, págs. 523-536.

829. FERnÁNDEZ, Tomás Ramón: «La organización territorial del Estado y la Administración pública en la nueva Constitución», en Id. (ed.): Lecturas sobre la Constitución española, Universidad Nacional de Educación a Distancia, Madrid, 1978, vol. 1, págs. 345-376.

830. FERnÁNDEZ, Tomás Ramón: «El sistema de distribución de competencias entre el Estado y las Comunidades autónomas», Revista de Estudios de la Vida Local, núm. 201, enero-marzo 1979, págs. 9-36.

831. Fernández, Tomás Ramón: «El problema de los límites de la potestad legislativa regional», Documentación Administrativa, núm. 182, abril-junio 1979.

832. Fernández, Tomás Ramón; Calvo Ortega, Rafael; Cosculluela, Luis; Linde, Enrique; Muñoz Machado, Santiago, y Parejo, Luciano: Las autonomías regionales, aspectos políticos y jurídicos, Instituto Nacional de Prospectiva, Madrid, 1977.

833. Fernández-Carnicero González, Claro José: «La institucionalización de las regiones en el contexto de reforma de la Administración Tributaria española», Revista de Economía y Hacienda Local, núm. 25, enero-abril 1979 (reproducido en Documentación Administrativa, núm. 182, abril-junio 1979).

834. FERrando, Juan: «Nación y nacionalidad», Estudios sobre el proyecto de Constitución, Centro de Estudios Constitucionales, Madrid, 1978, páginas $493-500$.

835. Fraga Iribarne, Manuel: «La institucionalización de la región», Documentación Jurídica, núm. 13, enero-marzo 1977, págs. 7-28.

836. García, Miguel A.: «La regulación de las autonomías», Argumentos, número 3, julio 1977, págs. 13-16.

837. García Javaloys, Joaquín: «Las autonomías regionales y la política económica», Documentación Administrativa, núm. 181, enero-marzo 1979.

838. García Oliva, Mario: «Y también razones históricas», Argumentos, número 16 , octubre 1978 , págs. $64-65$ (sobre Cantabria).

839. Gasoliba y Bohm, Carlos: «La financiación de las Autonomías en el marco de la Constitución», Libre Empresa, núm. 8, septiembre-octubre 1978, páginas 131-158.

840. Giménez Montero, Antonio: «El futuro de las autonomías», Argumentos, núm. 24, junio 1979, págs. 27-29.

841. Giménez Montero, Antonio; López Hernando, Juan José, y Pons AlbenTOSA, Leopoldo: «La autonomía y el federalismo fiscal», Nuestra Bandera, núm. 92, 1978, págs. 41-46.

842. González Casanova, José Antonio: «Notas sobre política autonomista en 
757. Cuco, Alfons; Dolc, Carles; Lluch, Ernest, y Soler, Vicent: «Els Països Catalans, un proceés unitari i divers», Taula de Canvi, núm. 3, enero-febrero 1977 , págs. $12-28$.

758. Dauder, Jorge: «La cuestión de las nacionalidades en España», Coyoacán, núm. 2, invierno 1977-1978.

759. EHAs: «Euskadi, nación oprimida», Materiales, núm. 5, septiembre-octubre 1977, págs. 123-133.

760. FERnÁNDEZ, Santiago: «El movimiento nacional en Galicia», Horizonte Español, 1966, Ruedo Ibérico, París, 1966, tomo II, págs. 111-116.

761. FERnÁNDEZ, Santiago: «Galicia y el problema de las nacionalidades», Cuadernos de Ruedo Ibérico, núm. 10, diciembre 1966-enero 1967, págs. 97-101.

762. FERrando, Juan: «Las regiones», en Fraga IrIbarne, Manuel (ed.): La España de los años 70, Ed. Moneda y Crédito, Madrid, 1974, vol. III, tomo I, págs. 499-540.

763. Ferrer, Juan: «E1 País Valenciano como problema. Experiencias y perspectivas», Cuadernos de Ruedo Ibérico, núm. 25, junio-julio 1970, págs. 53-57.

764. Gambra, Rafael: «Foralismo y nacionalismo vasco», Verbo, núms. 128-129, septiembre-noviembre 1974 , págs. 939-947.

765. Garmendia, José María: «El nacionalismo de izquierdas en la Euskadi de hoy», Argumentos, núm. 5, octubre 1977, págs. 25-28.

766. GARRABOU, Ramón: «Fet nacional i práctica política a Catalunya: alguns aspectes polémics», Materiales, núm. 2, marzo-abril 1977, págs. 5-13.

767. GERMán, Luis G.: «El nuevo aragonesismo», Negaciones, núm. 3, mayo 1977, págs. 147-159.

768. Gil-Calvo, Enrique: «Debate sobre 'milenarismo' vasco. Sobre sionismo vasco», El Viejo Topo, núm. 35, agosto 1979, págs. 20-25.

769. GISPERT, Carles, y Prats, Josep María: España: un Estado plurinacional, Blume, Barcelona, 1978.

770. GoItiA, Iñaki: «Algunas precisiones sobre Euskadi», Cuadernos de Ruedo Ibérico, núm. 25, junio-julio 1970, págs. 39-52.

771. González Casanova, José Antonio: «Posibilidades constitucionales de la regionalización en España», Seminario Bravo Murillo, Diputación Provincial de Badajoz, Badajoz, 1974.

772. Guatta, Aurelio: División territorial y descentralización, Instituto de Estudios de Administración Local, Madrid, 1975.

773. GuíA, Josep: «L'estructuració política dels Països Catalans», Taula de Can$v i$, núm. 3, enero-febrero 1977 , págs. 29-34.

774. HeIBERG, Marianne: «Insiders/Outsiders: Basque Nationalism», Archives Europeens de Sociologie, tomo 16, núm. 2, 1975, págs. 16-193.

775. Heine, Harmutt: «La evolución política en Galicia (1939-1975)», Cuadernos de Ruedo Ibérico, núms. 51-53, mayo-octubre 1976, págs. 21-49.

776. Herrero de Miñón, Miguel: Regionalismo y Monarquia, Madrid, 1977.

777. IKER: «Nacionalismo y lucha de clases en Euskadi (V y VI Asambleas de ETA)», Cuadernos de Ruedo Ibérico, núms. 37-38, junio-septiembre 1972, págs. $15-36$.

778. IzTueta, Paulo, y Apalategui, Jokin: El marxismo y la cuestión nacional vasca, Ed. Itxaropena, Zarauz, 1977.

779. Jiménez Blanco, José; García Ferrando, Manuel; López Aranguren, Eduardo, y Beltrán Villalba, Miguel: La conciencia regional en España, Centro de Investigaciones Sociológicas, Madrid, 1977.

780. López AdÁn, Emilio: «Lucha de clases en el País Vasco», Revista Mensual/ Montbly Review, núm. 6, octubre 1977.

781. López del Castillo, Lluis, y Riera, Ignasi: «El debat político a l'entorn 
de la llengua», Taula de Canvi, núm. 2, noviembre-diciembre 1976, páginas 52-71.

782. LÓPEZ DE Dicastillo GorRicho, Luis: «Naturaleza del nacionalismo vasco», Hemen eta Orain, núms. 1-2, enero-abril 1979, págs. 33-39.

783. LIISET BORRELL, Francisco: «La significación político-administrativa de la región en nuestro futuro inmediato», Documentación Administrativa, número 169 , 1976, págs. 49-76.

784. Mir6, Fidel: Cataluña, los trabajadores y el problema de las nacionalidades, Editores Mexicanos Unidos, México, 1967.

785. NúÑ̃z, Luis C.: Opresión y defensa del euskera. Clases sociales en Euskadi. La sociedad vasca actual, Txertoa, San Sebastián, 1977.

786. OrIol, M. (Jordi SolÉ-TurA): «Carles Cardó i la questió nacional», Horitzons, núm. 2, primer trimestre 1961, págs. 6-13.

787. Pardo, José Luis: «Debate sobre 'milenarismo' vasco. Xenofobia y xenofilia», El Viejo Topo, núm. 35, agosto 1979, págs. 14-19.

788. PaUl Arzac, Juan Ignacio, y OtAegui, Kike: «Diversas respuestas ante la cuestión nacional 'en Euskadi'», El Cárabo, núm. 4, enero-febrero 1977, págs. 49-68.

789. Pérez-Agote, Alfonso; Minondo, Agustín; Atucha, Karmele; Miranda, Beatriz, y ARAZÁBAL, Juan Luis: "Hacia una interpretación sociológica del País Vasco», Saioak, núm. 2, 1978, págs. 222-230.

790. Pérez Ayala, Andoni: «Euskadi: debate sobre la cuestión nacional», Materiales, núm. 5, septiembre-octubre 1977, págs. 115-122.

791. Peris, Vicent, y Sorolla, Guillem: «El País Valenciano. Problemas de la revolución socialista», Horizonte Español, 1972, Ruedo Ibérico, París, 1972, tomo 2, págs. 61-73.

792. PIÑEIRO, Ramón: «El regionalismo gallego», Razón y $F e$, núm. 917, junio 1974 , págs. $519-530$.

793. RECALDE, José Ramón: «Les nationalités en Espagne», Revue Internationale du Socialisme, núm. 4, abril 1967.

794. ReCAlde, José Ramón: «Pueblo Vasco y Nación», en el vol. colectivo Asalto, al centralismo, Avance, Barcelona, 1976, págs. 57-59.

795. Recalde, José Ramón: «La construcción de la nación vasca», Zona Abierta, núm. 11, 1977, págs. 44-56.

796. RIBó, Rafael: «Apuntes sobre la plurinacionalidad del Estado español», en el volumen colectivo Asalto al centralismo, Avance, Barcelona, 1976, páginas $7-28$.

797. RiB6, Rafael: Sobre el fet nacional. Catalunya; Pä̈sos catalans; Estat espanyol, Avance, Barcelona, 1977.

798. RoIG, Joan: «Veinticinco años de movimiento nacional en Cataluña», Horizonte Español, 1966, Ruedo Ibérico, París, 1966, tomo II, págs. 117-130.

799. Santamaría ANSA, Carlos: «En torno a la nación vasca», en el volumen colectivo Asalto al centralismo, Avance, Barcelona, 1976, págs. 51-57.

800. Silva Cienfuegos-Jovellanos, Pedro de: El regionalismo asturiano, Ayelga, Salinas, 1976.

801. SolÉ-TurA, Jordi: «La Qüestió de l'Estat i el concepte de Nacionalitat», Taula de Canvi, núm. 1, septiembre-octubre 1976, págs. 5-20.

802. TarabinI, Antoni, y Alomar, Celestí: «El Fet Nacional a les Illes avui i demà», Taula de Canvi, núm. 1, septiembre-octubre 1976, págs. 36-48.

803. TORNE JIMÉNEZ, J. C.: Ensayo sobre una administración regional en España, Universidad de Granada, Granada, 1972.

804. TxaBr: «ETA y la cuestión nacional vasca», Horizonte Español, 1972, Ruedo Ibérico, París, 1972, vol. 2, págs. 75-86. 
805. Vidal Villa, José María: «Catalunya: una nacionalidad oprimida», Negaciones, núm. 3, mayo 1977 , págs. 129-145.

806. Zubillaga, Iñaki: «Notas sobre la actualidad del debate histórico en Euskadi», Materiales, núm. 11, septiembre-octubre 1978, págs. 81-95.

807. Zugasti, Martín: «El problema nacional vasco», Horizonte Español, 1966, Ruedo Ibérico, París, 1966, tomo II, págs. 101-109.

\subsection{Nacionalidades y regiones en la Constitución de 1978}

807. AA.VV.: Federalismo y regionalismo, Centro de Estudios Constitucionales, Madrid, 1979.

808. Aguiló Lucía, Luis: «Los Estatutos de Autonomía y el control parlamentario», en RAMíREZ, Manuel (ed.): El control parlamentario del Gobierno en las democracias pluralistas ( $E l$ proceso constitucional español), Labor, Barcelona, 1978, págs. 316-326.

809. Aguiló Lucía, Luis; Franchi I Ferrer, Vicente, y Martínez Sospedra, Manuel: Volen l'Estatut! Per una autonomia possible per País Valencià, Prometeo, Valencia, 1977.

810. AlfÉREZ, Gabriel: «La regionalización en España», Documentación Jurídica, núm. 19, julio-septiembre 1978, págs. 693-761.

811. Alvarez Conde, Enrique: «Los titulares de la iniciaciativa del proceso autonómico», Revista de Estudios de la Vida Local, núm. 202, abril-junio 1979, págs. 233-256.

812. ARgullol, Enrique: «Preautonomía y traspaso de competencias: la Generalitat de Cataluña y sus funciones en materia de Urbanismo», Revista de Derecho Urbanístico, núm. 61, enero-febrero 1979, págs. 39-70.

813. ARgullol, Enrique: «Organización administrativa de las Comunidades Autónomas», Documentación Administrativa, núm. 182, abril-junio 1979.

814. Argullol, Enrique, y FerRet, Josep: «Autonomia universitaria i traspás de competències», Taula de Canvi, núm. 10, marzo-abril 1978, págs. 69-81.

815. Balaguer, Doro: «Partits, Constitució y autonomia al País Valencià», Nous Horitzons, núm. 47-48, octubre-noviembre 1978 , págs. 78-85.

816. BedoyA, Juan G.: «De la Ceca a la Meca, ¿Quién quiere la Autonomía?», Argumentos, núm. 16, octubre 1978, págs. $65-66$ (sobre Cantabria).

817. Bermejo Vera, José: «Cauces para la solución de los conflictos competenciales», Documentación Administrativa, núm. 182, abril-junio 1978.

818. Bordagarai, Kepa, y Pastor, Robert: Estatuto vasco, Eds. Vascas Argitaletxea, San Sebastián, 1979.

819. Carcasonne, Guy: «Les 'nationalités' dans la Constitution», Pouvoirs, número 8, 1979, págs. 117-122.

820. Clavero Arévalo, Manuel: Igualdad, uniformidad y variedad en el tratamiento constitucional de las autonomias, Granada, 1979.

821. Colom I PAStor, I.: L'Estatut d'autonomia de les Illes Balears, Barcelona, 1978.

822. Colom, Joam: «Autonomia i hisenda en el projecte d'Estatut de 1978», L'Avenç, núm. 20, octubre 1979 , págs. 32-36.

823. Colomer Viadel, Antonio, y Martínez Sospedra, Manuel: «Competencias regionales y su distribución en el marco constitucional», Estudios sobre el proyecto de Constitución, Centro de Estudios Constitucionales, Madrid, 1978, págs. 537-570.

824. Colomer Viadel, Antonio, y Martínez Sospedra, Manuel: «El control de 
las nuevas Cortes», La izquierda y la Constitución, Eds. Taula de Canvi, Barcelona, 1978, págs. 62-73.

843. González Casanova, José Antonio: «Los Estatutos de las Comunidades Autónomas y el principio de autogobierno», Documentación Administrativa, núm. 182, abril-junio 1979.

844. Huerta, Benito: «La Autonomía de Cantabria ante la Constitución», Argumentos, núm. 16, octubre 1978, págs. 61-62.

845. Juan y Penalosa, José Luis de: «El principio de solidaridad interregional. El principio de solidaridad y la regionalización de los impuestos», Documentación Administrativa, núm. 181, enero-marzo 1979.

846. LASARTE, Javier: «La financiación de las Comunidades Autónomas», Documentación Administrativa, núm. 181, enero-marzo 1979.

847. LÁzARo, Laureano: «Desarrollo y subdesarrollo ante las autonomías», Nuestra Bandera, núms. 88-89, 1977 , págs. 23-33.

848. Linde Paniagua, Enrique: «El delegado del Gobierno», Documentación Administrativa, núm. 182, abril-junio 1979.

849. López-Casanovas, Joan F.: «Menorca i la pre-autonomia», Nous Horitzons, núms. 47-48, octubre-noviembre 1978, págs. 50-55.

850. LevI, Franco: «Gli enti locali territoriali», La Costituzione Spagnola nel trentennale della Costituzione italiana, Arnaldo Forni Ed., Bolonia, 1978, páginas 125-131.

851. LuCAs Murillo, Pablo: «Nazionalità e Regioni nel processo costituente», en Vergottini, Giuseppe de (ed.): Una Costituzione democratica per la Spagna, Franco Angeli Ed., Milán, 1978, págs. 195-209.

852. Lliset Borrell, Francisco: «La función pública local en el marco de la Cataluña autónoma», Documentación Administrativa, núm. 176, octubrediciembre 1977, págs. 69-89.

853. Mafz, Ramón: «Las instituciones políticas en el Estatuto de Autonomía de Galicia (Notas para un debate)», Argumentos, núm. 20, febrero 1979, pá* ginas 25-27.

854. Martín Mateo, Ramón: «Le autonomie locali», La Costituzione Spagnola nel trentennale della Costituzione Italiana, Arnaldo Forni Ed., Bolonia, 1978, págs. 109-115.

855. Martín Queralt, Juan; Baixauli Almarche, Rafael; Berlanga Casanova, Antonio; Tomás Carpi, Juan Antonio; García AÑoveros, Jaime; Lozano Serrano, Carmelo; Peña Velasco, Gaspar de la; Tamatit Gimeno, Rafael: Vela Pastor, Manuel; Casas Pardo, José, y Aguirre, Javier: La financiación de las autonomías, Consellería de Economía y Hacienda del País Valenciano, Valencia, 1979.

856. Martín Rebollo, Luis: «Incidencia de la nueva organización territorial en los recursos contencioso-administrativos (el control jurisdiccional de las Comunidades Autónomas)», Documentación Administrativa, núm. 182, abriljunio 1979.

857. Martín-Retortillo, Lorenzo: «Gli enti locali territoriali», La Costituzione Spagnola nel trentennale della Costituzione Italiana, Arnaldo Forni Ed., Bolonia, 1978, págs. 117-124.

858. Martínez Genique, Alberto: «Financiación de los entes territoriales autónomos», Estudios sobre el proyecto de Constitución, Centro de Estudios Constitucionales, Madrid, 1978, págs. 619-656.

859. MuÑoz, Juan: «Las autonomías: el discutible problema fiscal», Transición, núm. 1, octubre 1978, págs. 39-43.

860. MuÑoz Machado, Santiago: Las potestades legislativas de las comunidades autónomas, Civitas, Madrid, 1979: 
861. Muñoz Machado, Santiago: «Sobre la burocracia de las Comunidades Autónomas», Documentación Administrativa, núm. 182, abril-junio 1979.

862. Obregón, Eduardo: «Las Autonomías, una cuestión política», Argumentos, núm. 16, octubre 1978, págs. 62-63.

863. Ortiz DíAz, José: «La Administración local en la regionalización», Documentación Administrativa, núm. 181, enero-marzo 1979.

864. PALAdíN, Livio: «L'ordinamento regionale in Spagna all'esperienza italiana», La Costituzione Spagnola nel trentennale della Costituzione Italiana, Arnaldo Forni Ed., Bolonia, 1978, págs. 133-140.

865. PARADA, José Ramón: «Constitución, burocracia y Comunidades Autónomas», Documentación Administrativa, núm. 182, abril-junio 1979.

866. Pedrós Abelló, Alejandro: «Principios de Hacienda regional», Estudios sobre el proyecto de Constitución, Centro de Estudios Constitucionales, Madrid, 1978, págs. 571-588.

867. PÉrez Ayala, Andoni: «El bloque dominante ante las Autonomías en las Nacionalidades», Argumentos, núm. 7, diciembre 1977, págs. 67-69.

868. PÉrez Jiménez, Pablo: «Federalismo fiscal y autonomías», Argumentos, número 4, septiembre 1977 , págs. 70-74.

869. PÉrez Moreno, Alfonso: «Técnicas jurídicas garantizadoras del principio de solidaridad regional», Estudios sobre el proyecto de Constitución, Centro de Estudios Constitucionales, Madrid, 1978, págs. 703-715.

870. Pérez Moreno, Alfonso: «Solidaridad y convenios entre Comunidades Autónomas», Documentación Administrativa, núm. 181, enero-marzo 1979.

871. PRATs, Joan: «Generalitat i Administració local en el període provisional», Taula de Canvi, núms. 8-9, noviembre 1977/febrero 1978, págs. 20-45.

872. Prats, Joan: «La provincia ante la Constitución y las autonomías», Documentación Administrativa, núm. 182, abril-junio 1979.

873. Remiro Brotons, Antonio: Territorio nacional y Constitución, Cupsa, Madrid, 1978.

874. Revilla, Miguel A.: «Razones económicas para la Autonomía», Argumentos, núm. 16, octubre 1978, págs. 59-60 (sobre Cantabria).

875. Rıвó, Rafael: «Autonomia i Constitutió», Nous Horitzons, núm. 36, octubre 1977, págs. 27-38.

876. Rıвó, Rafael: «Països Catalans: de la definició a la Constitució», Nous Horitzons, núms. 47-48, octubre-noviembre 1978, págs. 26-31.

877. Rosa, Leopoldo de la: «Los entes locales y la futura Comunidad Autónoma de Canarias», Información Comercial Española, núm. 549, mayo 1979, páginas 113-115.

878. Rubtales, Amparo: «Las Comunidades Autónomas: tipología y mapa territorial», Documentación Administrativa, núm. 182, abril-junio 1979.

879. SÁENZ DE BURUAGA, Gonzalo: «Las autonomías en España y la crisis del Estado nacional en Europa. Un enfoque fiscal», Estudios sobre el proyecto de Constitución, Centro de Estudios Constitucionales, Madrid, 1978, páginas 657-684.

880. Saiz Viadero, José Ramón: «Cantabria vs. Castilla-León», Argumentos, núm. 16, octubre 1978, pág. 58.

881. SAlAS, Javier: «Hacia una reestructuración de la Administración periférica del Estado», Documentación Administrativa, núm. 182, abril-junio 1979.

882. Serrano DE Triana, Adolfo: «La Constitución y la Administración autonómica», en FERNÁNDEZ, Tomás Ramón (ed.): Lecturas sobre la Constitución española, Universidad Nacional de Educación a Distancia, Madrid, 1978, tomo 2, págs. 241-266. 
883. Simón Acosta, Eugenio: La autonomía financiera de las regiones, Facultad de Derecho de la Universidad de Extremadura, Cáceres, 1978.

884. Simón ACOSTA, Eugenio: «La proyectada autonomía financiera regional», Estudios sobre el proyecto de Constitución, Centro de Estudios Constitucionales, Madrid, 1978, págs. 589-618.

885. Simón Acosta, Eugenio: «La financiación de las regiones en función de los bienes y servicios de provisión regional», Documentación Administrativa, núm. 181, enero-marzo 1979.

886. SolÉ-Tura, Jordi: «La batalla por las instituciones autonómicas», Argumentos, núm. 1, mayo 1977, págs. 18-22.

887. SoSA WAGNER, Francisco: «El control de las Comunidades Autónomas por el Estado en la Constitución española», Documentación Administrativa, número 182, abril-junio 1979.

888. TeixeIro PiñeIro, A.: Autonomias y Constitución. Notas para un debate estatutario, Santiago de Compostela, 1978.

889. ToRnos MAS, Joaquín: «La intervención de las Comunidades Autónomas en la economía», Civitas. Revista Española de Derecho Administrativo, número 21, abril-junio 1979, págs. 221-239.

890. Triana, Eugenio: «Los problemas de la autonomía en las regiones deprimidas», Nuestra Bandera, núm. 91, 1978, págs. 10-12.

891. Trías Vejarano, Juan: «El hecho nacional y regional: sus soluciones constitucionales», Nuestra Bandera, núms. 88-89, 1977, págs. 69-73.

892. Trujillo, Gumersindo: «La regionalización del Estado», Estudios sobre el proyecto de Constitución, Centro de Estudios Constitucionales, Madrid, 1978, págs. 501-521.

893. VANDELLI, Luciano: «Il rapporto Stato-regioni nella riforma costituzionale», en VergotTrini, Giuseppe de (ed.): Una Costituzione democratica per la Spagna, Franco Angeli Ed., Milán, 1978, págs. 211-227.

INDICE DE REVISTAS CITADAS

L'Actualité juridique. Droit administratif. París.

Administración y Progreso. Madrid.

Administration. París.

American Bar Association Journal. Chicago.

The American Political Science Review. Washington.

Amministrare. Milán.

Anales de la Universidad Hispalense. Sevilla.

Annales de la Faculté de Droit et des Sciences Politiques et Economiques de Strasbourg. Estrasburgo.

Annales de Philosophie Politique. París.

The Annals of the American Academy of Political and Social Science. Filadelfia. Anuario de Derecho Administrativo. Santiago de Chile.

Archiv des öffentlichen Rechts. Tubinga.

Archives Europeens de Sociologie. París.

Archivio di Studio Urbanistico Regionale. Milán.

Arguments. Valencia.

Argumentos. Madrid.

Asian Survey. Berkeley (Cal.).

Australian Quarterly. Sidney.

L'Avenç. Barcelona.

Boletín de la Facultad de Derecho y Ciencias Sociales. Córdoba (Argentina). 
Boletín Informativo de Ciencia Política. Madrid.

Boletín Informativo de la Fundación Juan March. Madrid.

The British Journal of Sociology. Londres.

Cahiers de l'Institut français des sciences administratives. París.

Cahiers Internationaux de Sociologie. París.

Canadian Journal of Economics and Political Science. Toronto.

The Canadian Review of Sociology and Anthropology. Toronto.

El Cárabo. Madrid.

The China Quarterly. Londres.

Las Ciencias. Madrid.

Ciencias Sociales. Moscú (en castellano).

Civitas. Roma.

Civitas. Revista Española de Derecho Administrativo. Madrid.

Communitá. Milán.

Comparative Studies on Society and History. La Haya.

Contradictions. Bruselas.

Courrier Hebdomadaire. Bruselas.

Coyoacán. México.

Critica Marxista. Roma.

Cuadernos Americanos. México.

Cuadernos Aragoneses de Economía, Zaragoza.

Cuadernos del Congreso por la libertad de la cultura. México.

Cuadernos Políticos. México.

Cuadernos de Ruedo Ibérico. París-Barcelona.

Documentación Administrativa. Madrid.

Documentación Jurídica. Madrid.

Documentación Social. Madrid.

Donauraum. Salzburgo.

Dossiers de l'Action Sociale Catholique. Bruselas.

Espaces et Societés. París.

Est-Ouest. París.

Estudios de Deusto. Bilbao.

Ethno-Psychologie. El Havre.

Études Internationales. París.

Etudes et Statistiques. Bulletin Mensuel. Cameroum. Afrique Equatoriale. Banque Centrale. París.

Far Eastern Economic Review. Hong Kong.

Il Foro amministrativo e delle acque pubbliche. Milán.

Gaceta Universitaria. Caracas.

Galeuzca. Buenos Aires.

Gibralfaro. Málaga.

Giurisprudenza costituzionale. Roma.

Government and Opposition. Londres.

Hemen eta Orain. Bilbao.

Historia Internacional. Madrid.

Historia Libertaria. Madrid.

L'Homme et la Societé. París.

Hotitzons. México (clandestina en España).

Ideología y Sociedad. Bogotá.

Información Comercial Española. Madrid.

Información Jurídica. Madrid.

Jábaga. Málaga.

Jahrbuch der öffentlichen Rechts der Gegenwart. Tubinga. 
Jornadas. México.

Journal des Tribuneaux. Bruselas.

Journal of Contemporary History. Londres.

Libre Empresa. Madrid.

Materiales. Barcelona.

Middle Eastern Affairs. Nueva York.

Il Mulino. Bolonia.

Negaciones. Madrid.

New York University Law Review. Nueva York.

Notes et Etudes Documentaires. París.

Nous Horitzons. México-Barcelona.

Nouvelle Revue Internationale. París.

Nuestra Bandera. Bruselas-Madrid.

Nuestras Ideas. Bruselas (clandestina en España).

Nuova Rassegna di Legislazione, Dottrina e Giurisprudenza. Roma.

Die öffentliche Verwaltung. Stuttgart.

Osterreichische Zeitschrift för öffentliches Recht. Viena.

Pacific Viewpoint. Wellington (Nueva Zelanda).

Pakistan Horizon. Karachi.

Politeia. Caracas.

Politica del Diritto. Bolonia.

Politica Internazionale. Roma.

Political Studies. Oxford.

Il Politico. Pavia.

Politique Etrangére. París.

Politische Studien. Munich.

Pouvoirs. París.

Problémes politiques et sociales. París.

Problemi del Socialismo. Roma.

Proceedings of the Academy of Political Science. Nueva York.

Public Administration. Londres.

Public Administration Review. Washington.

Quarterly Review. Londres.

Questions actuelles du socialisme. Belgrado.

Randa. Palma de Mallorca.

Razón y Fe. Madrid.

Realidad. Roma (clandestina en España).

Recerques. Barcelona.

Res Publica. Bruselas.

The Review of Politics. Notre Dame (Indiana).

Revista de Administración Pública. Madrid.

Revista Brasileira de Estudos Politicos. Belo Horizonte.

Revista de Catalunya. París (clandestina en España).

Revista del Colegio de Abogados del Distrito Federal. Caracas.

Revista de Derecho Público. Madrid.

Revista de Economía y Hacienda Local. Madrid.

Revista Española de la Opinión Pública. Madrid.

Revista de Estudios Políticos. Madrid.

Revista de Estudios Sociales. Madrid.

Revista de Estudios de la Vida Local. Madrid.

Revista de la Facultad de Derecho. Maracaibo.

Revista de la Facultad de Derecho de México. México.

Revista de la Facultad de Derecho de la Universidad Complutense. Madrid. 
Revista General de Legislación y Jurisprudencia. Madrid.

Revista del Instituto de Ciencias Sociales. Barcelona.

Revista Internacional de Sociología. Madrid.

Revista Jurídica de Cataluña. Barcelona.

Revista Jurídica de la Facultad de Derecho y Ciencias Económicas. San Miguel de Tucumán.

Revista de Letras. Mayagüez (Puerto Rico).

Revista Mensual/Monthly Review. Barcelona.

Revista Nacional de Economía. Madrid.

Revista de Política Internacional. Madrid.

La Revue Administrative. París.

Revue d'Allemagne. París.

Revue de Défense National. París.

Revue de droit international et de législation comparée. Bruselas.

Revue de droit public et de la science politique. París.

Revue d'Economie Politique. París.

Revue Française de Science Politique. París.

Revue Génerale Belge. Bruselas.

Revue Internationale des Sciences Administratives. Bruselas.

Revue Internationale du Socialisme. Roma.

Revue Internationale de Sociologie. París.

Revue Nouvelle. Bruselas.

Revue de Psychologie des Peuples. El Havre.

Revue de travaux de l'Academie des sciences morales et politiques. París.

Rinascità. Roma.

Rivista di Diritto Pubblico. Roma.

Rivista Trimestrale di Diritto Pubblico. Milán.

Saioak. Bilbao.

Sistema. Madrid.

Socialisme. Bruselas

Sociologia. Roma.

Sociología y Psicología Jurídica. Barcelona.

Soviet Studies. Glasgow.

Der Staat. Berlín.

Studium. Roma.

Taula de Canvi. Barcelona.

Les Temps Modernes. París.

Tiers Monde. París.

Transición. Barcelona.

Trimestre Político. México.

University of Cincinnati Law Review. Cincinnati.

Verbo. Madrid.

El Viejo Topo. Barcelona.

Vierteljahrshefte für Zeit-Geschichte. Stuttgart.

The Western Political Quarterly. Salt Lake City (Utah).

World Politics. Princeton (New Jersey).

Xaloc. México.

Yugsolav Law. Droit Yougoslave. Belgrado.

Zeitschrift für Ausländisches öffentlisches und Völkerrechts. Stuttgart.

Zona Abierta. Madrid. 